\title{
Life and letting die: A story of the homeless, autonomy, and anti-social behaviour
}

\begin{abstract}
If I were to say that the architecture in our public spaces is 'really speaking to us', you would be forgiven for thinking this is a piece about the aesthetics of our cities. In some ways in fact, it is, but not in any artistic sense. I am not discussing a collection of monuments, town houses or grandiose buildings. Alas, the architecture I talk of is more humble and yet perhaps more sinister. There is a message encoded into it, within our parks, streets and centres, which seems to be part of a wider narrative. This essay is an attempt to read it, find out what it says, and consider how that may affect our concept of autonomy, but also, to encourage us to reflect on how we choose to read it: to think on what theoretical framework we should discuss homelessness. The aim is not to necessarily reconceptualise something then, but is more in the tradition of making the familiar seem unfamiliar: not only in what we think, but how we come to think what we do and the extent to which the former is limited by the latter. To achieve this, the leading question I therefore ask is: what does the organisation of public space in reaction to a homeless presence tell us about autonomy, and how we think about autonomy?
\end{abstract}

\section{Keywords}

Autonomy, organisation, the homeless, anti-social behaviour, public space, normative theory, genealogy, biopolitics, Nietzsche, methods in political theory. 


\section{Prologue to a story: Nietzsche or normative?}

Like Jeremy Waldron's paper 'Homelessness and the Issue of Freedom' (1991) this essay is concerned with theoretical notions of autonomy and freedom when seen in the context of the homeless, but unlike that article, I begin with a Nietzschean framing, not a normative one.

Waldron's thought provoking piece is normative, because it presents prior moral criteria of negative liberty and appeals to 'abstract liberal principles' (Waldron, 1991, p. 295) to frame homelessness in a way that elicits concern: it structures a narrative, in which discomfort over policy is underpinned by a sense of power (for both the reader and the author) regarding normative framing as a starting point. Essentially, these prior principles are set up to be reinforced by a narrative. Instead, I hope to tell a story of the homeless that does not simply confirm this conceptual security, but unsettle it. This is done through exploring how the homeless subject is constructed.

The question which leads this essay is Nietzschean, it seems to me, because it begins from a place of method rather than principle: a historical inquiry searching for subtle shifts which over the years combine to form our current perception. But why start from this place? Mainly, because I do not seek to impose a principle onto a story to reinvigorate that principle, but rather tell a story to see what concepts come out of it. Or perhaps more specifically, I offer this narrative of homelessness to see how our familiarity with the idea of autonomy fairs, to recognise its confines, whilst gently placing a question mark over a normative framing and its origin point of perfectibility.

It should be noted however, that this apparent methodological origin does not claim to do away with prejudices and (ironically, being a genealogical approach) arrive at objective origins (Strauss, 1988, p. 11): merely that our starting point is not a moral framework, but a 
commitment to a non-moral, historicised one, which will subsequently allow us to think with prejudice.

Thus, there is a qualitative difference, I think, between starting from a moral prejudice, and allowing it into your reflection. As the latter is read without the distortion of a moral framework prior to the story, the narrative produces the moral discussion, rather than the principle imposing itself upon the narrative. When the normative reflections arrive later on, so to speak, they do so more as 'shows' and not 'tells'. Readers can approach them more cynically, for they already know the story, and are suspicious that somebody now tries to tell them what it means. It is easier to challenge claims made in such a way and makes the story closer to a real 'conversation' (Oakeshott, The Voice of Poetry in the Conversation of Mankind, 1962, p. 489) More normative theorists need to recognise that non-moral starting points can sometimes provide more inclusive frameworks for their normative discussions. A piece of work like Rawls' 'A Theory of Justice', for example, effectively starts by saying 'if you do not subscribe to the principle of wealth redistribution there is little point in engaging you': other positions and ideas are, in effect, 'convicted in advance of irrelevance' (Oakeshott, 1967, p. 202), and exactly 'why these issue should be regarded as pressing is left to one side' (Haddock, 2011, p. $68)$.

If we build our concepts and resolve our commitments to them from within a narrative, rather than impose them onto it, I believe we can arrive at a more critical understanding which is not insensitive to historical construction. Thus, in this problematization of autonomy through a story of anti-social behaviour and the homeless, there is the implicit claim that when normative theory is applied as a prior moral framework to an investigation, conceptual analysis is immediately restricted. In essence, putting something 'at the beginning as the beginning', as this style of doing normative theory does, is to disable or limit such reflection (Nietzsche F. , 2005, p. 168). 
Hence, I begin the essay with an alternative eye, from a view few of us experience: a (micro) genealogy, with real historical moments (albeit quite recently - not all genealogies have to be over vast expanses of time), told through an imagined story. I invite critics to answer the questions our detective protagonist asks, but can never himself resolve. The risk here is a lost reader: without foundational normative commitments to emphasise the awfulness of homelessness the reader (and author even) may find themselves a little abandoned. This is not the intention. Essentially, I wish for the normative commitments to emerge from the story, having fought their way through, not to have been imposed from on high. This piece then, can perhaps be seen merely as a conversation (re)starter, which of course, anything which promises to make the familiar seem unfamiliar must be.

Finally, if I wish for the concept of autonomy to be made strange, challenged and seen from various angles that the theorist does not in the main start from, it discomforts me to inflict a singular definition of it. But it is my hope that the following essay will untangle that, rather than fortify it. Consequently, here at least, we must have some idea in order to know what we are discussing, to be able to recognise one of its faces when it emerges. With this in mind then, I understand autonomy to be associated with the following: to act as a willing, conscious agent in achieving one's desires. I would go on, but I fear I have already said too much.

\section{The Story}

And so now, to the matter at hand. Let us begin with a detective who is looking for somebody. He immediately catches our attention because he is standing stock still amidst a place of constant movement, in fact he seems to have more in common with the granite statues around him. This is exaggerated by the grey trench coat he wears, cutting a silhouette from the blurred images that pass by. He is not in motion yet because he is thinking, drawing on a cigarette. As the orange glow from its end ebbs away he goes to throw it on the floor, then checks himself, 
and puts it in a little metal disposal box, attached to the wall. He has been leaning against the smoothed cement of a building, which has been carefully designed to make it look older than it actually is. It is a bank, and it is not yet open. He takes a deep breath before he propels himself into the white-water rush of the street.

Now he is walking, fast and with purpose, like everybody else. He weaves in and out, navigating through the crowd with twists and turns. He passes market stands setting up their wares for the morning, council workers fixing electrical boxes, and commercial boards that make a sound like an elevator as they shift from one advert to another in repetitions every sixty seconds or so. He takes no notice of all of it. He has an important job to do. A fugitive is on the run and he has been tasked with finding him, but unfortunately the evidence is thin on the ground. Luckily, there is one lead: a witness. The detective has an artist's interpretation of her. Normal procedure would be to match that picture with visual records and find an address. From there he could visit the witness, take a statement, and follow up on anything that arose from it. This time is different however, hence why he has been put on the assignment: our detective has an intimate knowledge of the city from the days before he got a desk job. This is helpful, for in this case the witness is homeless and sleeping rough. Despite his senior position, he does not mind that he has been asked to take to the streets again. It provides a nice refreshing change.

The detective has already prepared his plan of action: that was why he was thinking whilst partaking in a smoke a moment ago, to go over everything one last time in his mind. He has considered what a day in the life of the witness involves and constructed his search accordingly. As such, he has focused his attentions upon the centre of town. He has decided on this for a few reasons. First, he is certain there will be more instances of public space architecture here that could be used by a rough sleeper, like benches and chairs. They will attract our witness because they provide a semblance of comfort, not just in a physical sense, but with a sentiment of the familiar: somewhere one goes to sit and lay down after a long day, or before it begins. 
The bridges and bus shelters nearby can be used in this way too, but can also cover one from the rain. Second, facilities like public toilets are more likely to be found here than in residential areas, again, not only offering physical comforts but a feeling that one is a person who goes to the bathroom like anyone else and not a rogue who urinates anywhere. Third, the commercial square and parks are places of motion, people moving from one shop to another, from a café to the bank. Consequently, it is a good base for a homeless person, even early in the morning: as commuters pass by there will be more opportunities to acquire money, either from asking for spare change or performing some street entertainment. Finally, we assume someone who sleeps rough would like to do so in a fairly public place, to ward against any potential dangers being alone in the middle of the night may present, or in the very least, reduce the overwhelming sense of vulnerability such an act may evoke. CCTV cameras keep an eye on these people, in all senses.

On top of all this, he has acted on the old saying that has made his career such a success - 'the early bird catches the worm' - by getting up at the crack of dawn along with the early commuters. The logic is simple: the witness cannot hide behind doors or locks (which would mean the detective obtaining a warrant) so if he should find her still sleeping, he can begin his questioning immediately. All he has to do then is look for somewhere that a homeless person could sleep around here.

With this in mind, he begins by heading to those park benches: as mentioned, a sensible initial step in our enquiry. As if noticing for the first time, he realises something new. Whether it be through the modification of old benches or the introduction of new ones with a different design, it is impossible to lay down on them. The result is strange-looking. In the modified ones there is still that attempt to look older than they actually are, harking back to a bygone age with quaint Victorian or Georgian curves masquerading as arm rests. The new benches however are often separated not by physical obstructions, but with space, a gentler method of organization. 
They are more like a grouping of chairs than a bench. The detective smiles wryly, for this reminds him of the change in prison cells, from a single room forcibly divided by bars to separate rooms in themselves. After a brief search coupled with such musing, it becomes apparent that he will not find her sleeping here. It is still early though. He has many more places to look so he is not at all anxious.

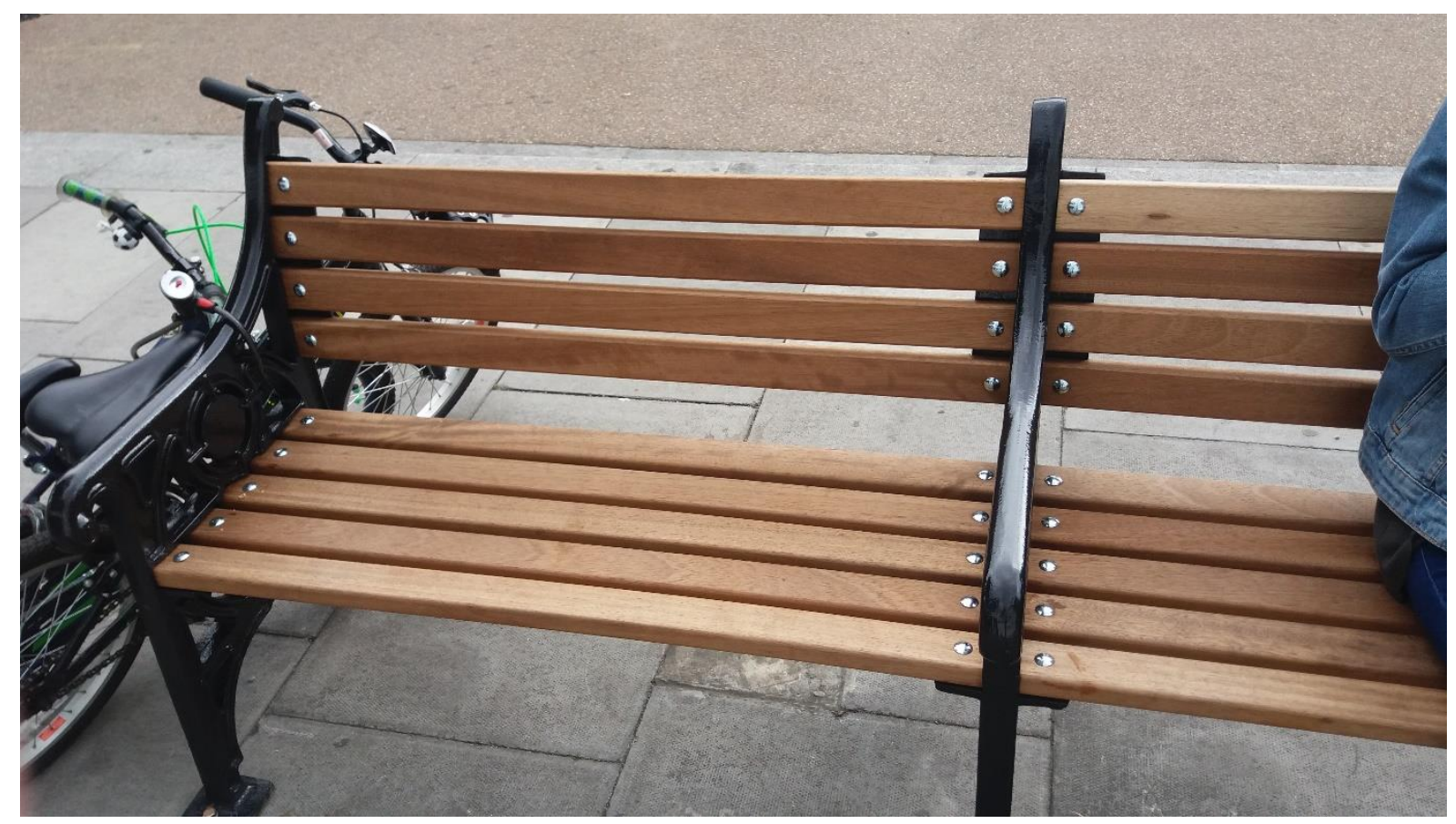

Figure 1 This picture (above) was taken by myself at Holloway in London, on 14/9/16 


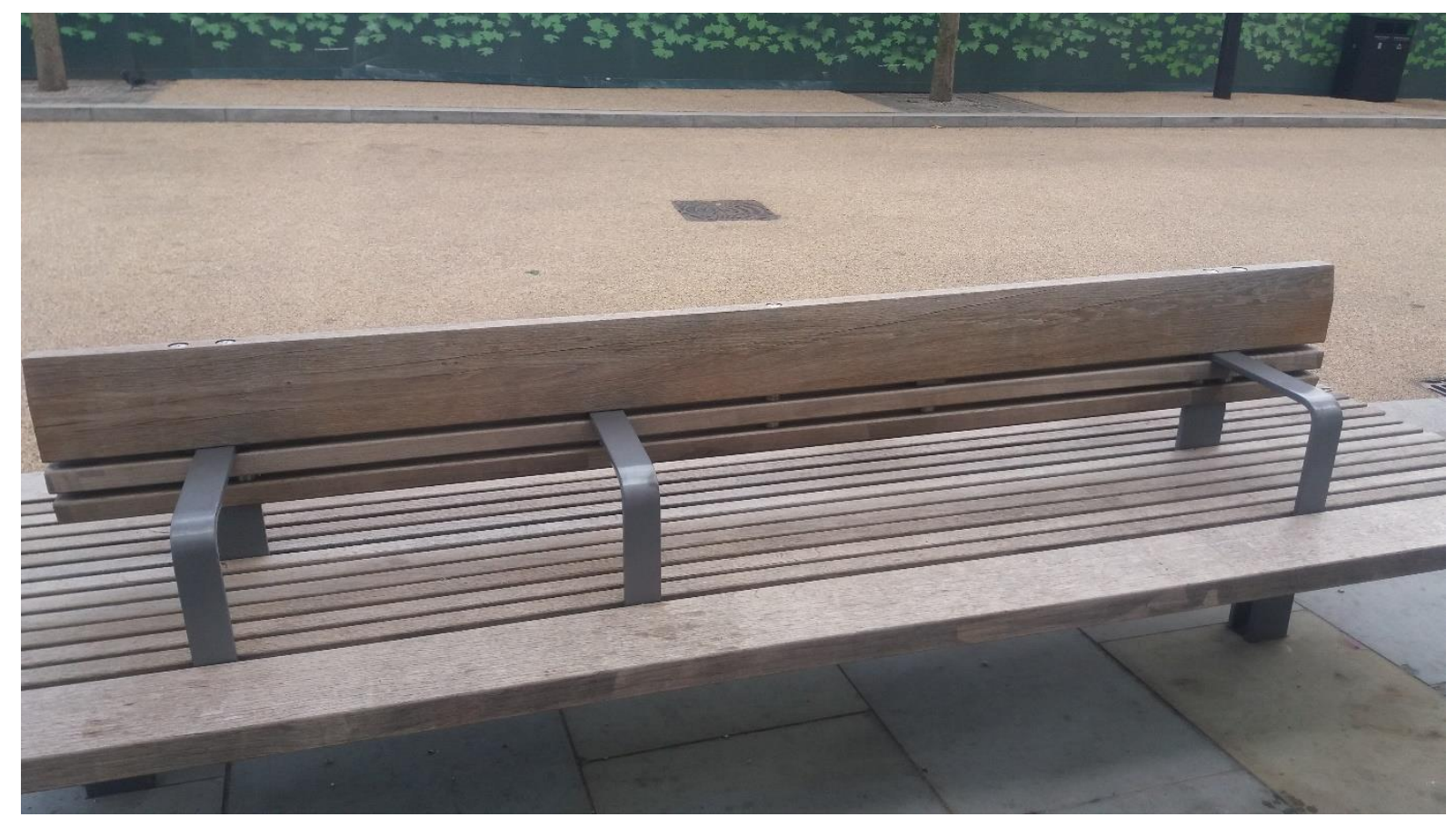

Figure 2 A bench (above) near King's Cross underground station (image taken by myself 15/10/16)

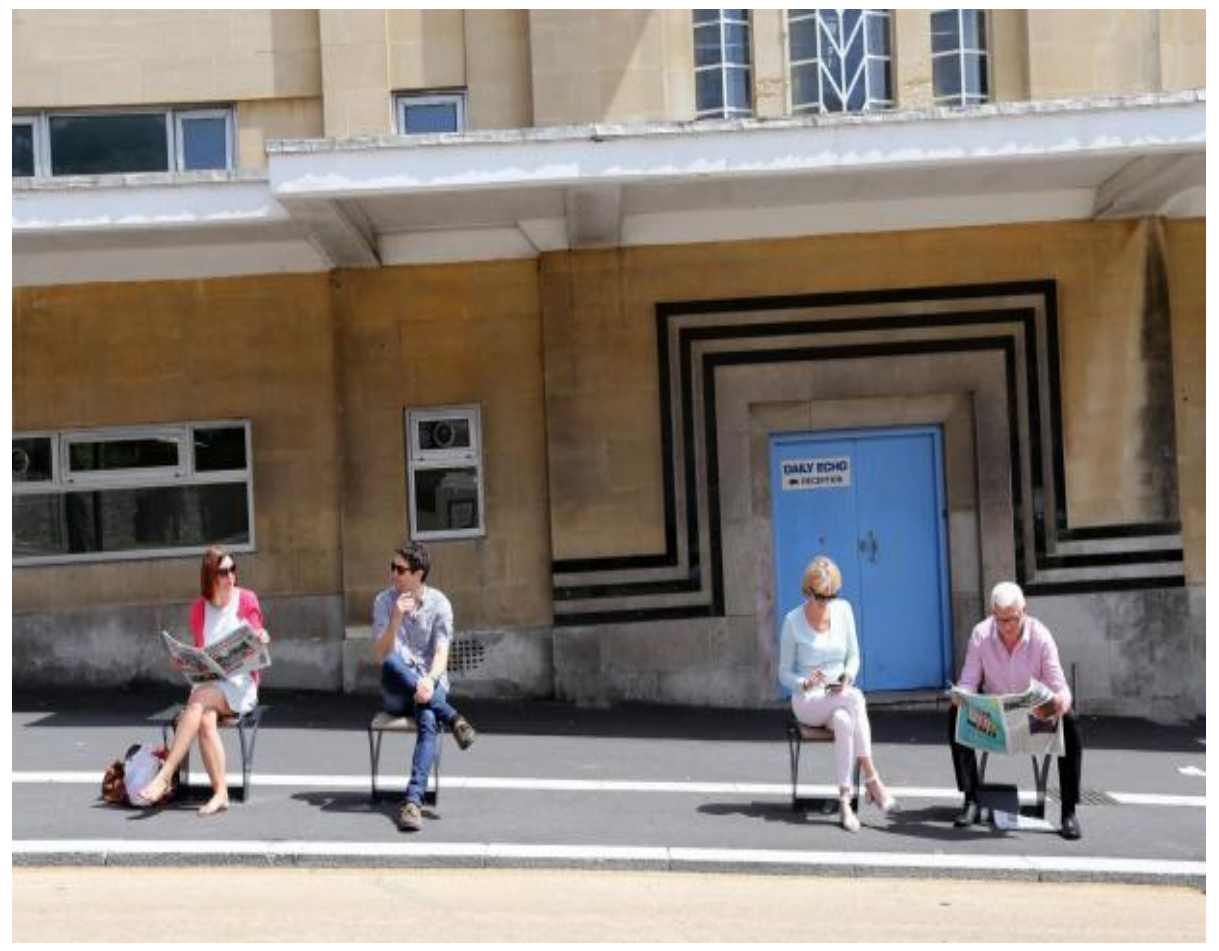

Figure 3 Image taken from:

http://www.bournemouthecho.co.uk/news/13368418. The most expensive in Bournemouth The four public seats whi ch cost over 1000 EACH/ 
He shrugs his shoulders and decides to look into the bus shelters, for they too have seats and the extra bonus of a roof cover. When he gets there, he finds that in a similar fashion these have been modified to better organize its use as a place of motion. Again, he realises he never noticed this before, just as he had never thought about how the bus shelter frames are now windows, allowing all eyes in. He sits in a rehearsed, almost meditative manner, trying to imagine her coming here the previous evening and re-enacting her actions in a kind of hunting ritual, now seeing night whilst everyone else is currently still living in the day. He does not hurry, taking this opportunity to once again stop, think, and allow movement to pass around him: it helps him achieve the sense of dislocation he needs to get into his prey's mind-set. There is streetlight pouring in through the bus shelter window frames, forcing her to huddle up and hide her face from the glare. Like a secret onlooker, he observes her past ghost trying to get comfortable. He imitates her and soon realises that after a while one begins to slip off the seats as they have been angled slightly downwards, threatening to drop him back into the moving current of the street. His legs begin to ache as he pushes against gravity, until he relents and gets up, once more back with everyone else in the daytime. This is not a place to make anchor. She must be sleeping somewhere else. 


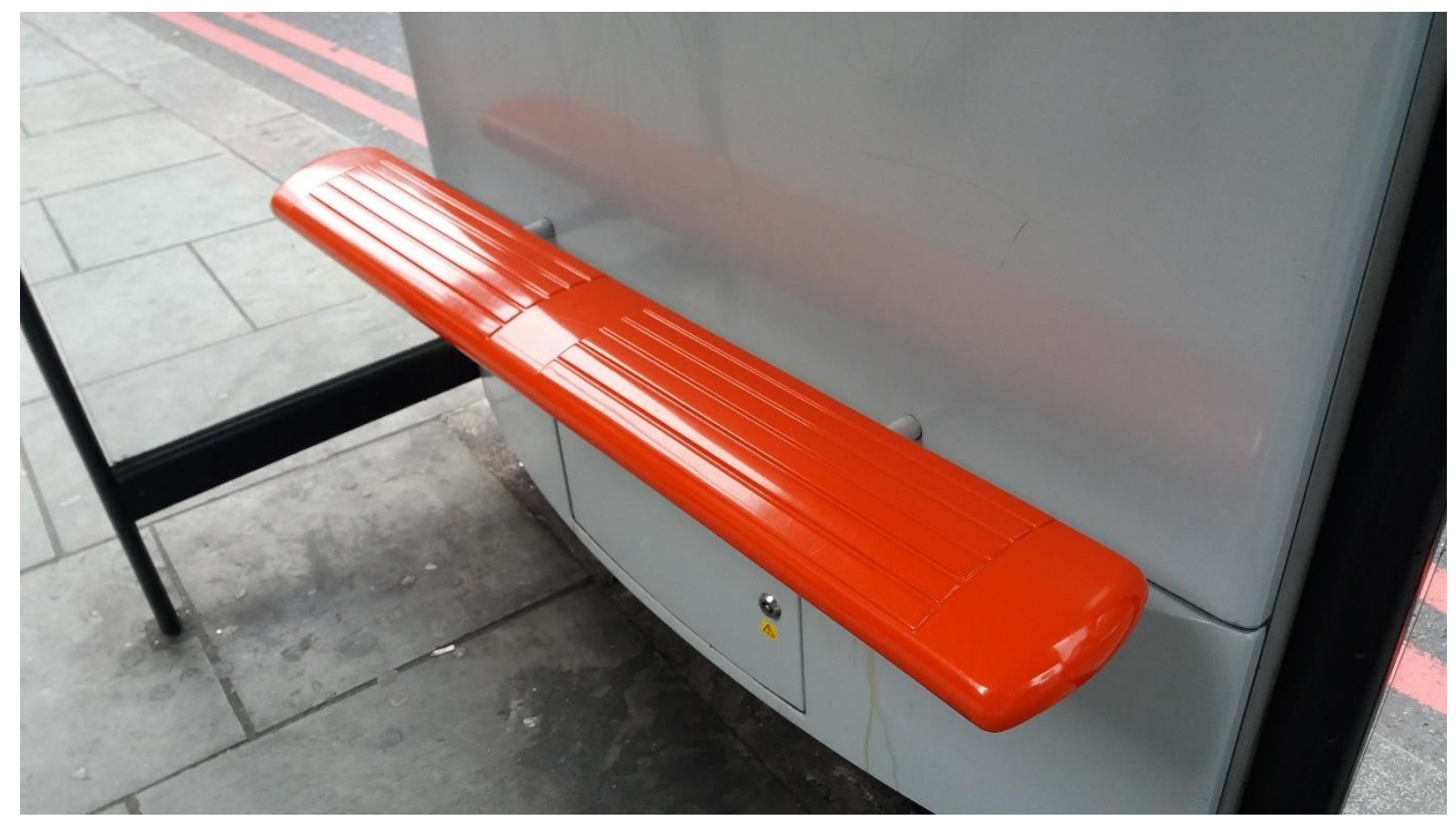

Figure 4 Like most bus shelter seats, this one on Liverpool Street in London is designed with a slight downward curve (image taken by myself 19/9/16

The detective heads to the train station, another place that would seem to make sense for the pursuit. Sure enough, benches have been designed here too to prevent laying down, brown wooden planks or metal poles cleanly placed at exact intervals. The second wave of commuters are arriving to the calming sound of classical music played over the station tanoy, washing all before them as they flood though barriers and into carriages. It is only when he comes across a discarded newspaper that he learns that during the night, from midnight to 6.30am, the soothing strains of Mozart are replaced by bagpipe recordings, played loudly, on a constant loop (Durkin, 2015). The detective glances across the story, picking out the key points: 'Earlier this year the Echo reported how commuters felt intimidated by the growing numbers of rough sleepers congregating at the travel interchange'. Then, further down the article: 'One coach station worker, who asked not to be named, said: 'Basically, the council has been playing bagpipe music through the night and it seems to be doing the job. They just cannot stand it, you try getting any sleep with that going on'. The feeling here is very much that although 'Rough sleepers have rights', 'so do the other citizens, workers and businesses': they 'have the 
right not to be intimidated or to have to face the daily ordeal of belongings left in doorways when they arrive for work' (Council E. C., www.benbradshaw.co.uk, 2015). It seems the tanoy provides a dual purpose and function, organizing the inside of the station into day and then night, first a space for gathering, then a space for dispersing. He will not find her here.

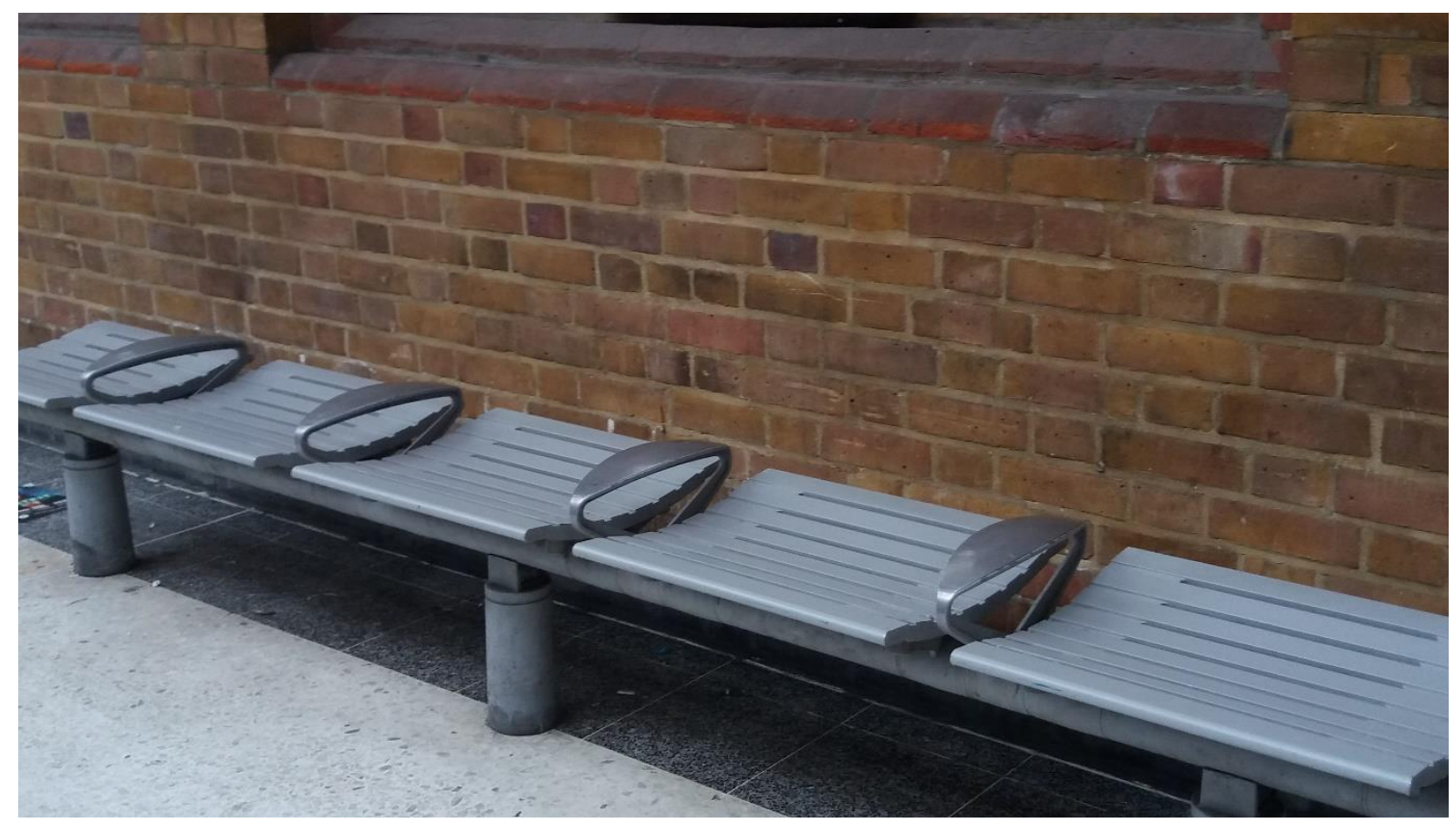

Figure 5 London Liverpool Street station (image taken by myself 19/9/16) 


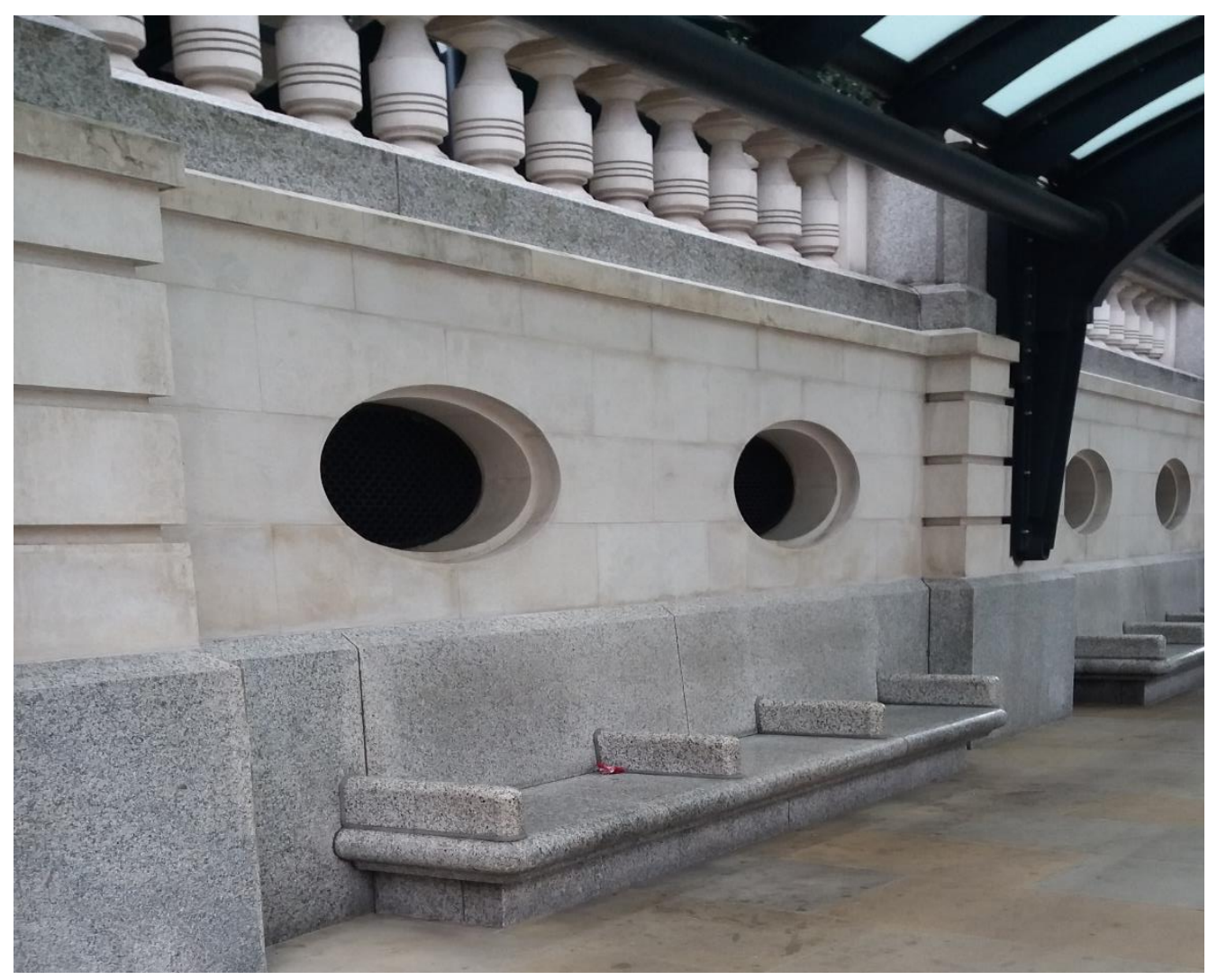

Figure 6 Near London Liverpool Street Station, where commuters walk to work (image taken by myself 19/09/16)

Beginning to get annoyed at having found no concrete leads he does not sit to think on his next step, but ponders whilst on the move. Luckily, the architecture around him offers a helping hand. Hope flares when he sees a bridge, safely taking cars over the heads of pedestrians without disturbing the flow of traffic with red lights or crossings. Surely, this will prove fruitful. His pace increases, impatient now to complete his task. At the beginning of the morning it was refreshing, but now it is becoming irritating. Yet, when he arrives his hope is crushed: under the bridge are cemented shapes and blocks that make all but standing there for a few minutes painful. In a passing consideration, this hostile architecture brings to his mind the image of the anti-pigeon spikes used to keep pests away. She could not have slept here either. 


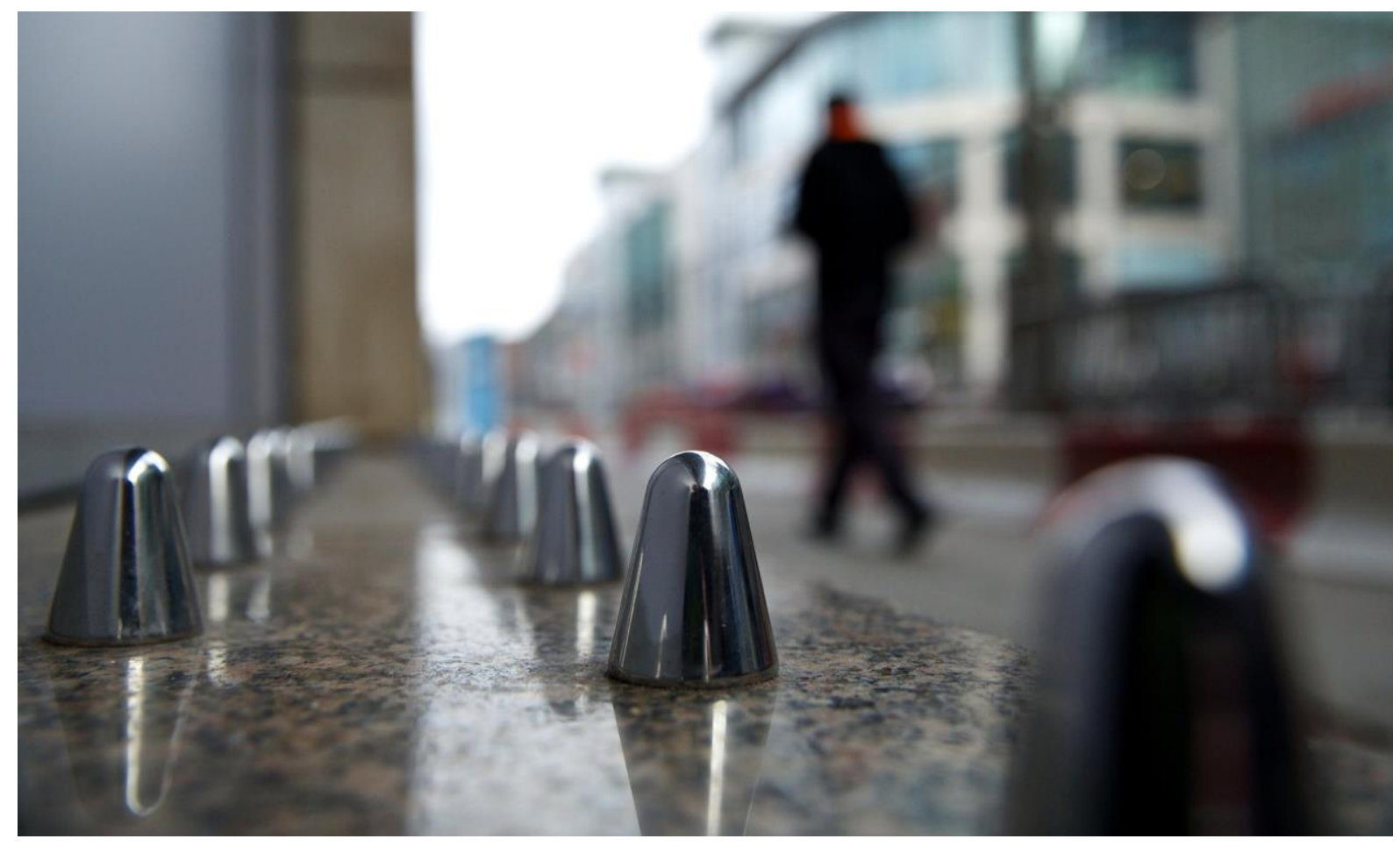

Figures 7 Spikes outside Selfridges in Manchester (photo taken by Christopher Thomond for the Guardian https://www.thequardian.com/society/2015/feb/18/defensive-architecture-keeps-poverty-undeen-and-makes-us-morehostile\#img-4

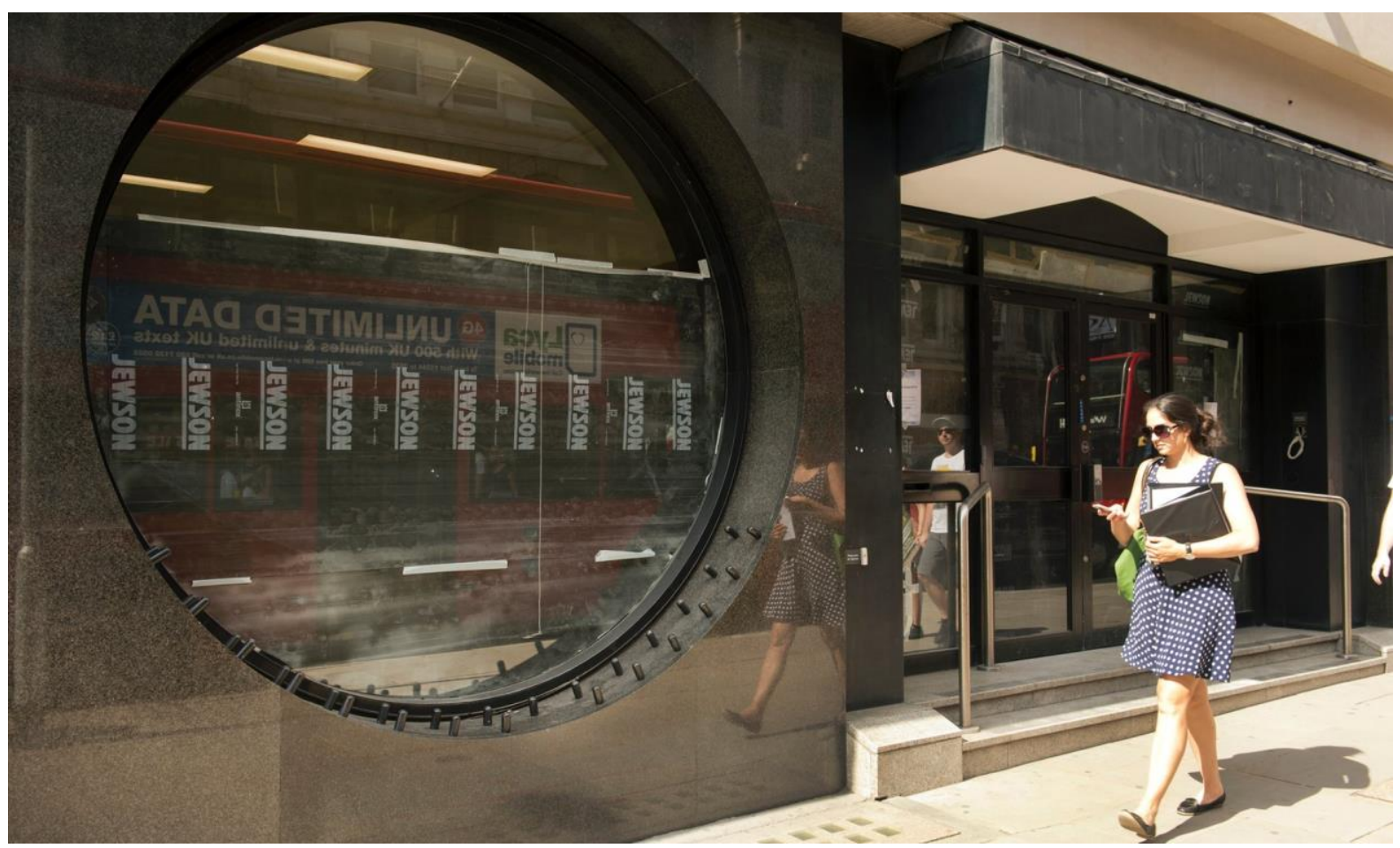

Figure 8 Fleet Street, London (Image taken by Linda Nylind for the Guardian -

https://www.theguardian.com/society/2015/feb/18/defensive-architecture-keeps-poverty-undeen-and-makes-us-morehostile\#imq-2 
The search continues onto the public toilets. Hardly a place suitable for sleeping, but he is getting desperate and frustrated. It is quieter here, but the absence of people around the bathrooms is understandable: it is still very early. Perhaps a good place to have a thorough look after all, if he can stand the smell. Like many localities however, when he comes to the entrance, he finds them not yet open from being locked overnight. Still, he cannot complain at having another place crossed off his list: graffiti sprayed across the lavatory doors seems to justify such measures.

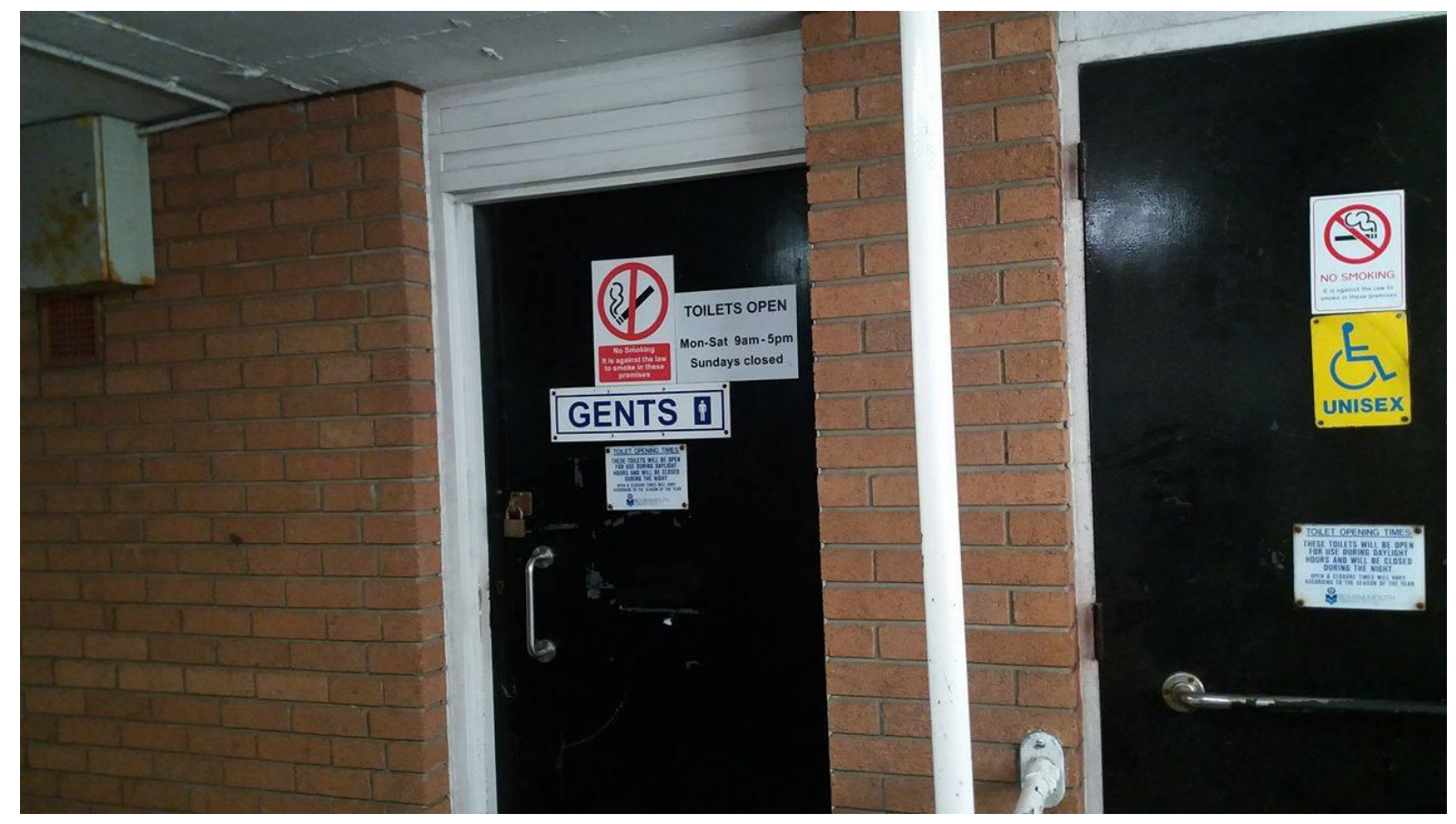

Figure 9 Locked toilets in Richmond Hill multi-storey car park in Bournemouth (above), like the train station, also accompanied by bagpipes music played on repeat (image taken by myself 15/5/16) 


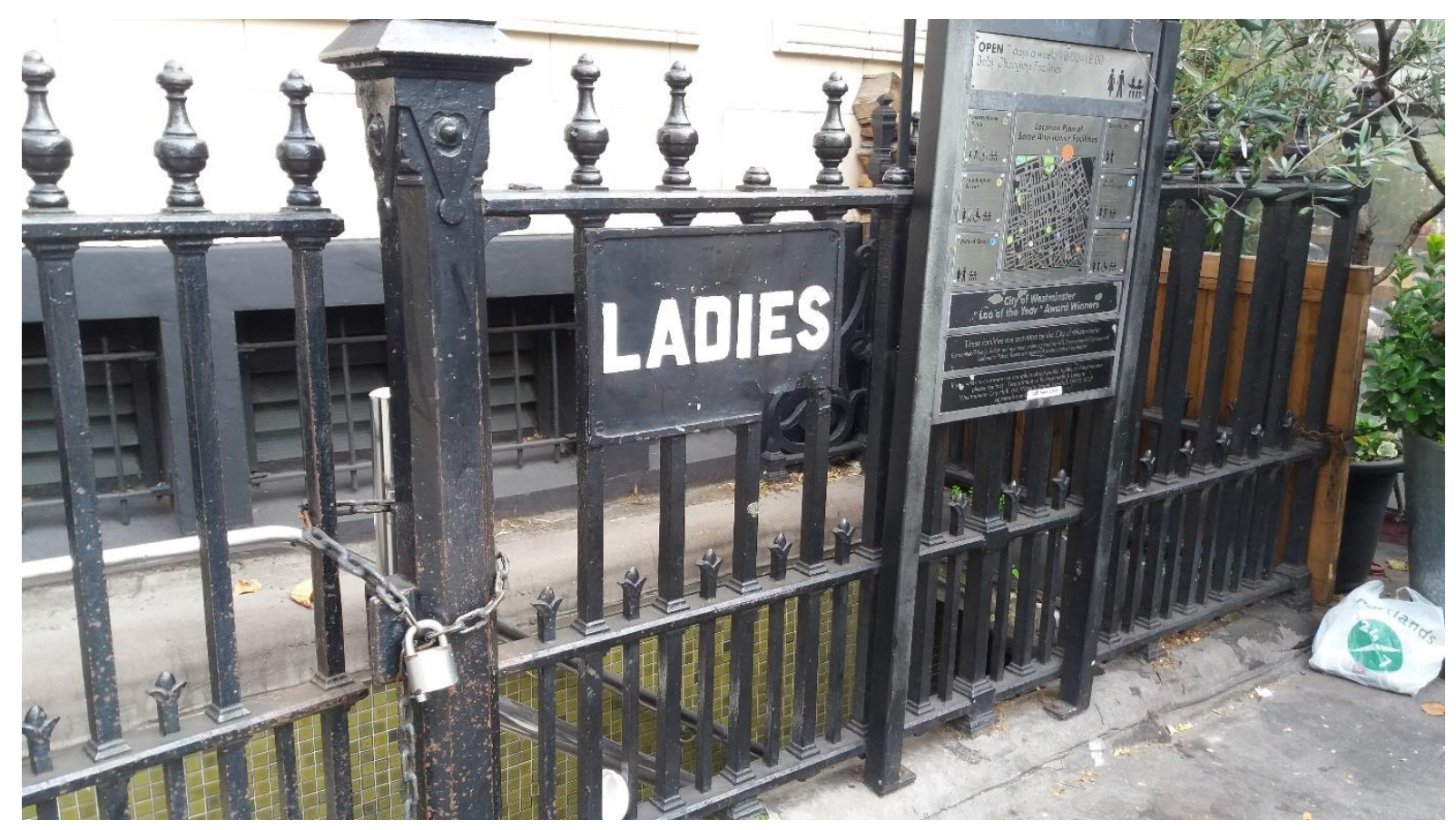

Figure 10 These toilets near Regent's Park are permanently closed (image taken by myself 23/11/16)

He moves on to the more commercial side of the high street, but realises he should have come here first: it is now past 9am and shoppers and tourists have fallen in with the flow, though in more meandering and slower currents than the commuters. He feels he should be able to quickly pick out any homeless people from their appearance and conduct. Most easily spotted, though, are the community support officers maintaining a leisurely ambience of 'casual, accidental encounters' (Parkinson, 2012, p. 147) as they look to move rough sleepers on from the crevasses and doorways lining the streets. Some stragglers remain but they are being woken up and sent on their way: duvets discarded or carried with them. This complicates the detective's search. He quizzes one of the officers, stopping her work. She protests. She tells him a Public Spaces Protection Order has recently been implemented in this area to prevent anti-social behaviour, and she is simply carrying out her duty to disperse and confiscate (Office, 2014, pp. 32-38) (Council C. B., 2015) (Council H. B., 2015, p. 1). 
He empathises and relents: she is only doing her job after all, to maintain a town centre with a welcoming atmosphere for members of the public. Even so, it does nothing to calm his increasing exasperation and the beginnings of an uncomfortable voice scratching away at him that he cannot quite yet grasp. She is right and yet this is wrong. Feeling himself being pulled into distracting thoughts he shakes his head to re-focus: he can always pick these musings up and ponder over their abrasive emergence again later anyway, in his own time. There are more immediate problems right now. Urgency overcomes all contenders. 


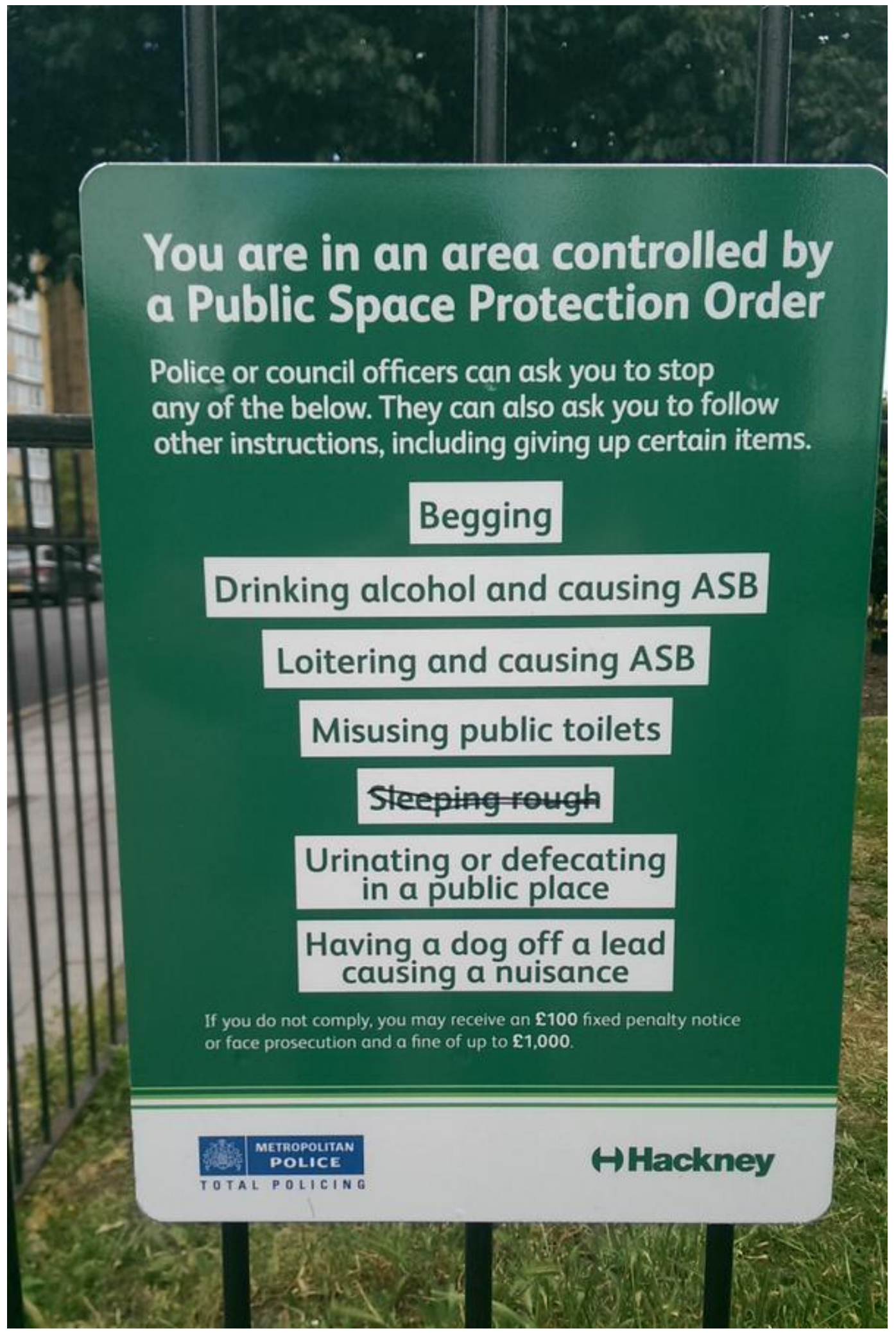

Figure 11 Though 'sleeping rough' was amended due to a campaign protesting such prohibitions (Osborne, 2015), the other equally troubling ones remain, working in tandem with the physical changes (which effectively maintain the legislative prohibition on sleeping regardless). (Image taken from https://hackneyrenters.org/2015/06/05/hackney-council-backdown-on-plans-to-fine-rough-sleepers/) 
But where now? He realises he may have made a grave error: he has discovered that sleeping in the most public of public spaces - the town centre - is a difficult task to perform and it is likely the homeless witness found a place hidden away, or perhaps further out. He looks across the square, the whitewashed paving stones glaring in the sunlight, already beginning to trace a likely route out of the centre in his mind's eye. Almost immediately he pauses and goes to get a closer look at the homeless individuals being dispersed. Something is stirring in his detective senses once more. She is not amongst them, and they have been moved on because they violated the PSPO the community officer was talking about. If his witness slept outside of the town centre however, beyond the reach of the order or at least out of sight of those who enforce it, she will not have been 'guilty', so presumably could come here now. He is certain she would indeed want to: she will return in daytime because she is as much bound to the town centre as anyone else is, if not more so. Her very survival relies upon consumption, in a way that is even more pressing than the people already here shopping. Similarly, the activity of acquiring money for consumptive capability, in an immediate sense at least, requires individual acts of charity from those shoppers, particularly since taking food waste from supermarket bins has been repackaged as a crime (Gentleman, 2014). It is obvious then that not being able to freely access such a place would make her life extremely more difficult. His mind working this through, he decides to take a different tack and rather than go looking for her, position himself in a place where she is likely to find him. He has a kind face and quite often gives food to homeless people. This could work in his favour.

He finds a refuge from the busy streets, in the form of a café. It has nice little seats outside it, spilling out a regulated distance into the square. This is good, on two points. First, he will have a view of everyone that passes by, and so will likely catch a glimpse of her if she is indeed heading into town. Second, although a homeless person is not likely to come inside and ask customers for change (the explicit sign informing everyone that the toilet here is for customers 
only reinforces that presumption), if he sits right on the very edge of the seating arrangement, he might be far enough from the glares of the waiters to catch the attention of a beggar: perhaps even her.

Because he is now doing something that demands patience, the detective goes over the witness profile again to himself. As a homeless person, he knows she can only be in public space, for this is a physical space that allows for access where one does not have to immediately 'secure the permission of anybody' (Waldron, 1991, p. 297) to be present, and allows for a 'fairly indeterminate range of uses' (Waldron, 1991, p. 298). If she was trespassing private space there would have been a call to the office: one cannot just camp on someone else's property. Yet as soon as he thinks this he begins to consider what he has seen with the PSPO. Effectively, its use has impacted upon his understanding of public space by refining what activities one can do here under the justification of anti-social behaviour. Never one afraid of accepting when he has made a mistake, he realises he needs to know more regarding exactly what this PSPO prohibits, if his latest plan is to be successful: if sleeping disturbs the tranquillity of public space, then it is quite probable begging might be included in the PSPO also.

Luckily this café has Wi-Fi so he need not go back to the office. He reaches into his bag for his tablet. A quick browse reveals that the PSPO was part of the 2014 Anti-social Behaviour, Crime and Policing Act. It enabled council boroughs to introduce penalties to forms of behaviour they deem to have a 'detrimental effect on the quality of life of those in the locality' and are 'persistent' (Crown T. , www.legislation.gov.uk, 2014, p. 33). He was right to listen to his instincts regarding this then. He reads on. Once in place the PSPO can have its jurisdiction range 'increased' (Crown T. , www.legislation.gov.uk, 2014, p. 33) to cover a wider or previously unaffected area. This is important to know, for it appears to be legislation which prevents the performance of anti-social behaviour by imposing geographical prohibitions. It seems simple enough, but his brow furrows as his practiced eye catches something which 
complicates matters. A PSPO can be brought in if 'it is likely that such activities will be carried on' and that 'they will have such an effect' (emphasis added): it is therefore able to impede someone on the premise that they may cause a disturbance in the affected area.

The detective grows concerned, this could be problematic for him. If the PSPO can be implemented on the basis that someone could do something anti-social then this is a gamechanger: should something in the PSPO's list of misbehaviours include an activity his witness cannot really avoid, then her presence here at any time can be called into question. He has already seen that resting here is problematic, and, given resting is something a homeless person will definitely have to do at some point in the day, does this mean his 'quarry' can, potentially, always be removed from the town centre, simply on the premise that she is 'likely' to rest? He must consider such things. She will for instance, have to at some point urinate and if the toilets are still locked, or as in London, have been converted to pay-to-use even when open, then he is more likely to have luck looking in the dark corners and alleyways of the town. At the very least, he should conduct his search ahead of the march of the community support officers, lest they scare away his target. The constant threat of their presence adds a significant stress to his pursuits. 


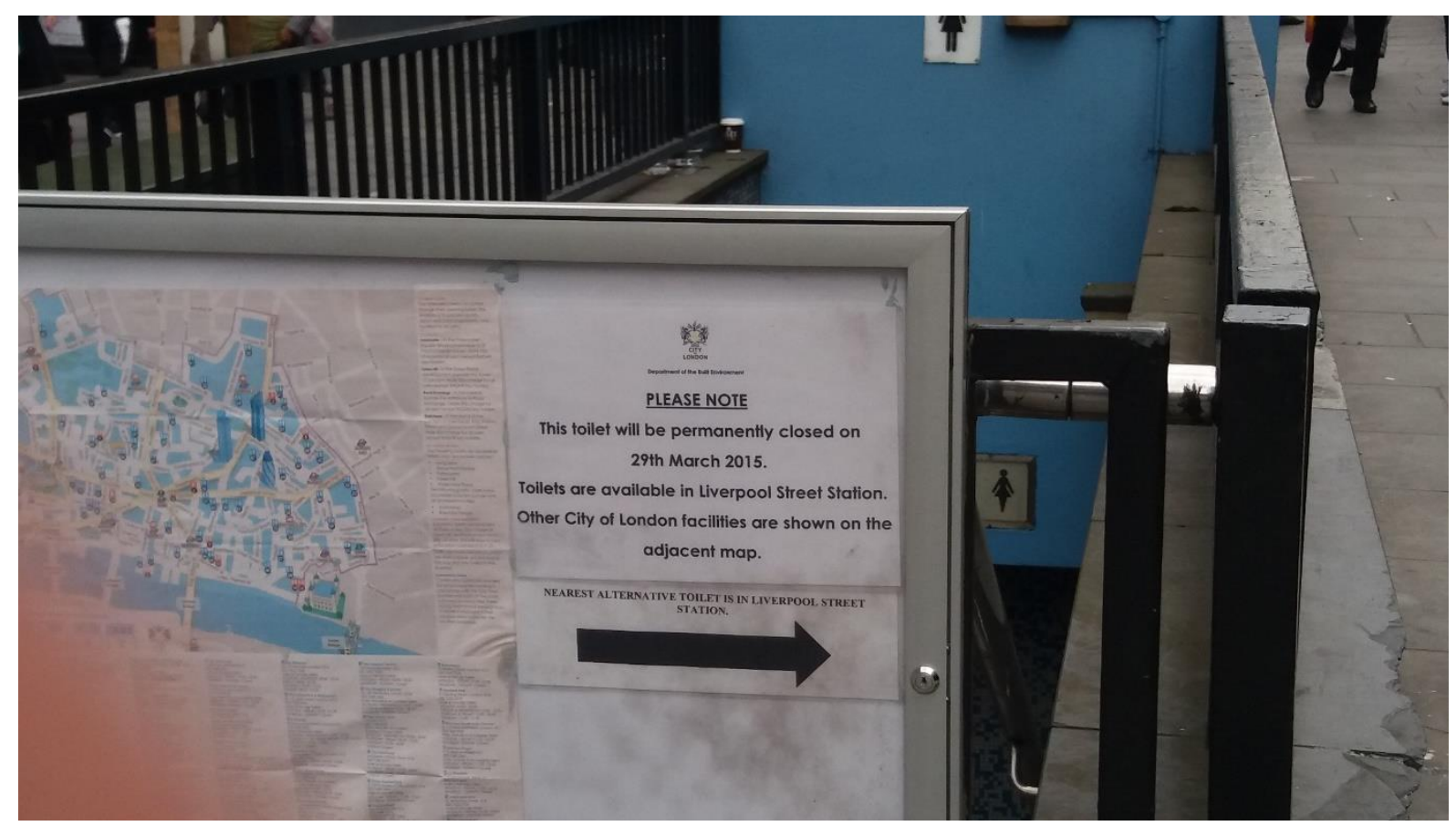

Figure 12 This closed toilet on Liverpool Street helpfully informs that toilets are available at the station...

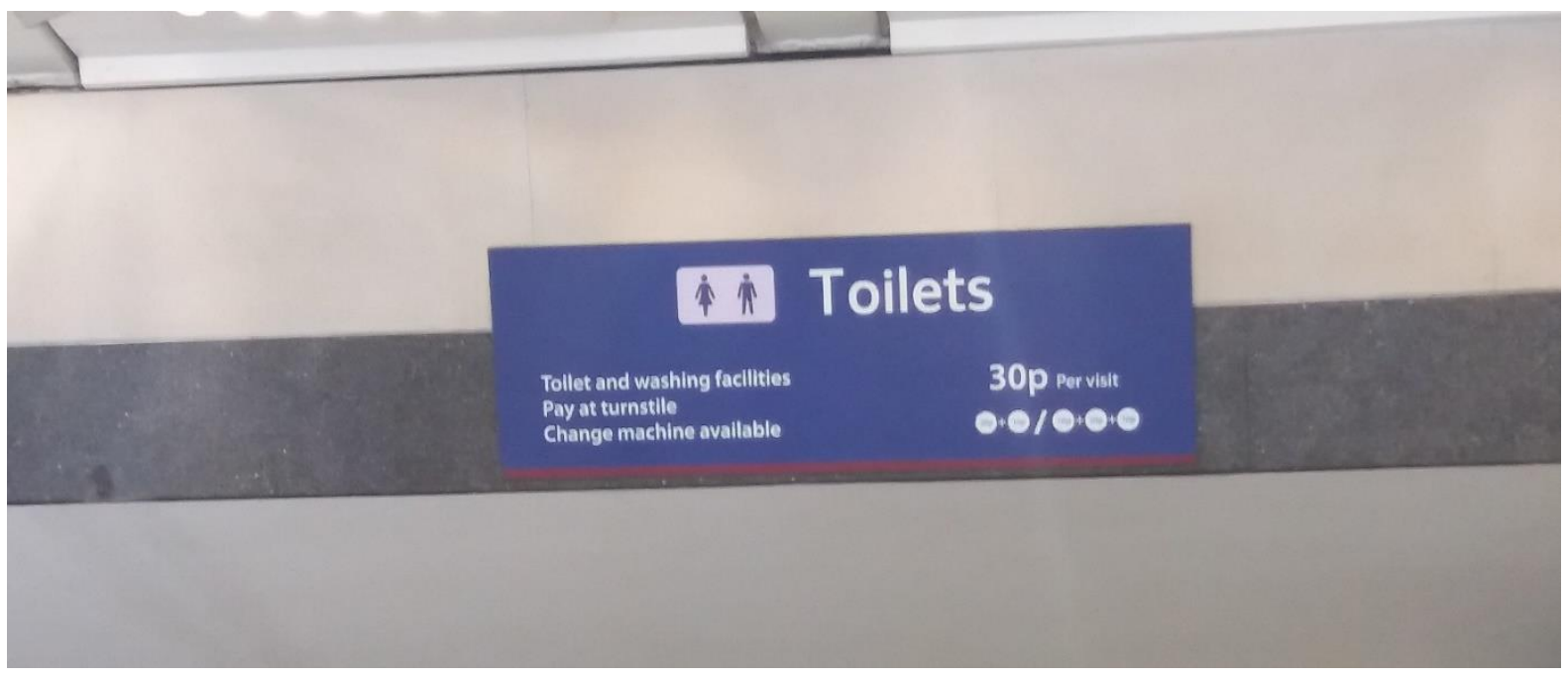

Figure 13 ...but London Liverpool Street Station, like most London travel interchanges, charge for toilet use (both images taken by myself 19/09/16)

He swiftly realises the PSPO could thwart this new 'bait' approach he is conducting at the café. If she could potentially be dispersed before she has even done anything considered 'anti-social' she may be prevented from stepping into his trap. In this agitated frame of mind, he scrolls down his internet browser findings to learn more. He discovers that should a 'new issue' arise where a 'PSPO is in force', the council can 'vary the terms of the order at any time' (Office, 
2014, p. 51). A PSPO's remit can therefore be expanded to include new misbehaviours as they present themselves as a 'persistent' problem. This could mean that the community support officers may have been told to keep an eye on current culprits of anti-social behaviour, defined by the PSPO, to see if the order has left anything out. A kind of anti-social behaviour profiling of potential offenders whose constructed 'anti-social' identity dictates, to some extent, what is considered an offence: her identity becomes a 'series of probable events' (Foucault, 2009, p. 20) which will occur unless actively prevented or moved on. In either case, he uncomfortably acknowledges, she is further exposed to the difficulties of street survival.

As if confirming this thought he learns that a PSPO 'can be targeted against certain behaviours by certain groups at certain times' (Office, 2014, p. 46): it is thus capable of singling out specific types of people, like the homeless witness. This confuses the detective a little, as he first presumed the PSPO was a geographical prohibition, focused on misbehaviours and not identities. As he sees an aspect of it moving more toward the latter, he is increasingly irritated at himself for not looking into this before he left the office this morning. He summarises what he has discovered: if her presence is a signal that anti-social behaviour will occur, and she cannot avoid doing whatever is prohibited, she is at a constant risk of being apprehended. He has read enough regarding its implementation, it is now imperative that he learn what else is covered in this specific PSPO. 


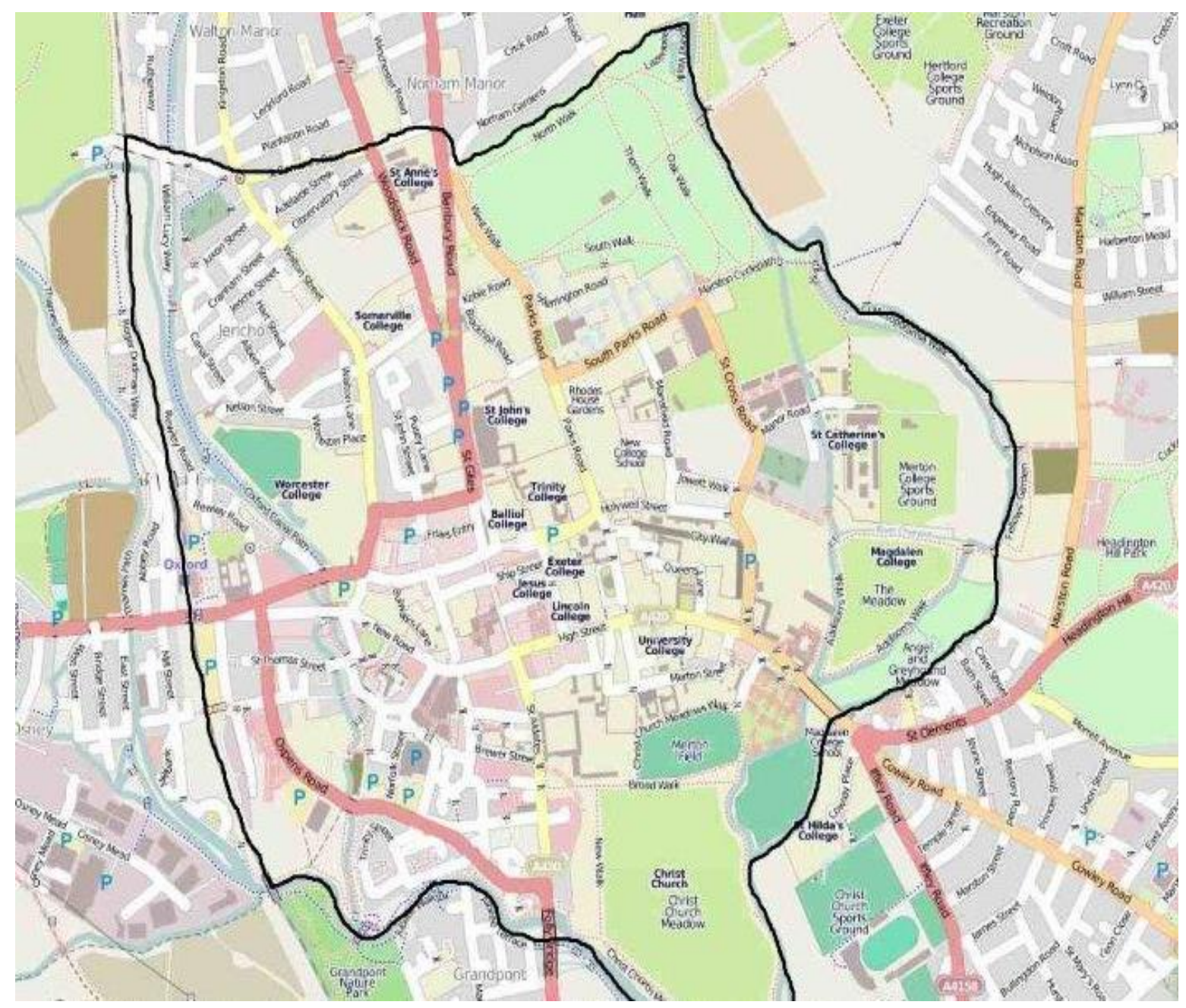

Figure 14 A map of the PSPO implemented in Oxford City Centre safely insulating the public pathways to the university colleges, which includes 'aggressive begging' and the very specific 'No person shall remain in a public toilet without reasonable excuse' (Council O. C., www.oxford.gov.uk/downloads, 2016) (Image taken from https://www.oxford.gov.uk/downloads/file/2264/oxford city centre pspo)

The waiter is hovering around, implicitly suggesting the detective has been here longer than a single cup of coffee would allow. He orders another. He is not yet prepared enough to re-enter the streets. In truth, he acknowledges to himself the PSPO caught him unawares. It has been quite some time since he was on the beat, doing the rounds as a police offer. But even then, he has to admit, there were signs, and he should have taken some time considering this before he came out this morning. A short trip down memory lane would have saved him time. He takes it now: better late than never. 
He distantly recalls the 2003 Anti-social Behaviour Act, introduced to refine exactly what antisocial behaviour was as the previous reference to it in the 1994 Crime and Disorder Act, he remembers, was particularly vague, defined as 'Acting in a manner that caused or was likely to cause harassment, alarm or distress to one or more persons not of the same household (as the defendant)' (Crown T. , The Crime and Disorder Act 1998 Chapter 37, 1998, p. 2). As a junior officer, on the few occasions he had been sent out to anti-social calls, he had experienced problems with this definition himself, as it seemed to imply a relational aspect to it which then awkwardly translated as locational: if people involved must not be of the same household, antisocial behaviour occurred outside of the home. This was not to say one could not experience it whilst inside their own houses, but that the place where misbehaviour occurred must be beyond the site of the 'power of decision' (understood as the power to determine who can and cannot be present that comes with being in our own private property) (Waldron, 1991, p. 297). Secondly, it gave a very weak categorisation of what might be termed anti-social, by placing it in the feelings and emotions of the individual who was supposedly suffering it. Unlike our private property, as individuals in public space, we exist in an area where both people we are familiar with and people we 'do not know personally', may enter into 'close interaction' with us without our 'explicit consent' (Guess, 2003, p. 13). As we do not have 'power of decision' to remove them here, instead, we rely upon public space legislation to replace, as far as possible, this lost power, so individuals are limited to behave in a way that does not force them self 'on anyone's attention' (Guess, 2003, p. 14). If they did, that was when he, as a junior officer on the beat, was told to intervene.

Being young, ambitious and astute, he had quickly realised this did little for actively defining anything officially as anti-social. Rather, it placed such an understanding completely into a changeable context: an organizing 'script' of behaviours shaped by 'culture, law or physical barriers' (Parkinson, 2012, pp. 56, 61). What specifically, in terms of actual actions and not 
feelings, would cause alarm, or should be considered as such? Understanding that had been important, for anti-social behaviour was considered a 'quality of life' issue for local communities and perceived as adding to an environment of 'disorder, fear of crime and more serious crime' (Crown T. , Police Research Series Paper 123: Policing Anti-Social Behaviour, 2000, pp. 1-2). He remembered his superior telling him as much. As a concept anti-social behaviour had previously been linked to traveller communities, ravers and disaffected youths ${ }^{1}$. By being posited in individual responses and emotions rather than concentrating more on the types of activity which would elicit such reactions, acting on anti-social behaviour had caused him and his colleagues 'practical difficulties' in regards to both identifying and dealing with it on a local level (Crown T. , Police Research Series Paper 123: Policing Anti-Social Behaviour, 2000, p. iii). Since he had ascended to the desk, things had apparently changed. The balance had tipped to specifying the forms of activity on the presumption of the feelings it elicited. The detective realises what the challenge had been: to maintain a flexibility to the definition so that it may be utilised to deal with localised problems, yet not allow that very flexibility to disempower the (now 'community') police officer when confronted with something potentially 'anti-social'.

Logging into the local e-library, he finds a research paper that was published by the Home Office, linking anti-social behaviour to the 'Broken Windows Theory' (Kelling, 1982). This theory, conceptualised by Wilson and Kelling in 1982, argued that 'high levels of disorder' would lead residents to 'assume that crime, especially violent crime, is rising' (Crown T. , Police Research Series Paper 123: Policing Anti-Social Behaviour, 2000, p. 3). The resulting

\footnotetext{
${ }^{1}$ In part V of the Criminal Justice and Public Order Act 1994 can be found 'Powers to remove unauthorized campers' and 'Powers in relation to raves' (Crown T. , www.legislation.gov.uk, 2016) . In regards to the antisocial 'youth', anti-social behaviour as an identity profiling was introduced into urban life. These remnants remain: Oxford City Council's 2015 PSPO includes a prohibition on 'Young people under the age of 21 years not legally resident in Foresters Tower' from 'entering (or having entered, remaining within) Foresters Tower, Woodfarm, Oxford unless visiting a named legal resident of Foresters Tower' (Council O. C., Foresters Tower Public Spaces Protection Order, 2016)
} 
feelings of fear and insecurity, of the assumption that no one cares about an area, would make it 'vulnerable to crime' (Crown T. , Police Research Series Paper 123: Policing Anti-Social Behaviour, 2000, p. 3). The Anti-social Behaviour Act was part of the continuing efforts to narrow the concept down then, and was a progression on the previous definition of anti-social behaviour in that it was an attempt to identify not only what it could be specifically, but what it could cause, to enable effective policing of an area. The intent of the Home Office was to offer a 'practical framework' to categorise anti-social behaviours (Crown T., Defining and Measuring Anti-social Behaviour, 2004, p. 4), enabling and encouraging a 'range of approaches' to be enforced at a 'local level' (Crown T., Defining and Measuring Anti-social Behaviour, 2004, p. 1). Yet, what also seems to be happening, is forging a direct association between a homeless presence and crime, and what is more, in the consequent dispersal strategies, constructing that into readable signs: legislation may exist like a hidden text, but the presence of a community support officer makes it visible, and alongside the physical changes - a modified park bench for example - the anti-social profiling is there for all to see and interpret. Anti-social behaviour discourse begins to take the homeless presence into consideration.

Sure enough, more suggestive refining of legislation appeared here. 'Setting fires', 'indecent exposure' or 'inappropriate sexual conduct', made it a problem for a homeless individual to have a warming fire on a freezing morning, or an intimate, sexual relationship, at all (Crown T. , Defining and measuring anti-social behaviour, 2004, p. 4). He realises there are some interesting aspects to this typology, particularly that the setting of fires is 'not directed at specific persons or property' (Crown T. , Defining and measuring anti-social behaviour, 2004, p. 4). Although this may seem odd at first glance it is what is to be expected within an antisocial behaviour remit: should such a fire be started with the intent of damaging someone's property, it becomes a criminal offence, and the province of the legislation should not be to 
punish crime, but to prevent our 'discomfort' and 'alarm'. This is a significant distinction, for the destruction of someone's property in such a manner has no connection to protecting oneself from the cold: he indeed would definitely dismiss any claim made in this way. Punishing an individual for burning down another person's house is most likely going to be justifiable, regardless of the circumstances, not only because of the result of the act but its inherent threat: the implied intention. However, the implication here is that making a fire for making a fire's sake should be prohibited, because it causes alarm, now that street braziers are not such a familiar sight. He agrees, but unlike a fire which is 'directed at specific persons or property', there is no further qualification on what this 'anti-social' fire is for, only what it is not. Would (and should) the response of the community officer be the same then, if he or she knew that the setting of a particular fire was to stave off hypothermia at 7am on a freezing January morning? Would the 'alarm' and 'distress' of commuters seeing this still be considered qualitatively more important than the physical discomfort of the homeless individual? One hopes not, but then this would imply that the fire was an autonomous act in terms of it being rational, but not in terms of it being a choice, for surely enduring a freezing January morning is an act within a paradigm of involuntary homelessness: if it is not vandalism or a provocative threat then it is an immediate survival strategy in response to the individual's homeless situation, which therefore cannot be a voluntary choice. He thinks to himself: no one would choose this specific set of circumstances and therefore should not be punished for it?

Surely this changes everything - not just the fire, but the benches, the bagpipes and the PSPO itself - certainly these 'behaviours' are not something to be 'punished away' from public space if we consider them as a survival strategy. His questioning goes a step further: should a survival strategy be the measure by which we allow 'misbehaviours'? Is this our only yardstick or criteria? Does this mean there is a point where survival strategy blends into autonomous act, disqualifying its performance? Considering this, he wonders, is the 'right' to not be essentially 
prevented from having sexual partners less important than the discomfort of a shopper who witnesses such activity in the street? He remembers the locked toilets. Sex confuses him. Its prohibition here is not because it is an illegal act in itself, but because it is a taboo of place, but then, much of what is prevented could also be judged in the same way.

When he considers the initiatives and the physical modifications he has seen, he realises that with these kind of changes there is absolutely no room for flexibility regarding 'survival' acts (and the grey areas such as sex) - a concrete arm rest cannot 'turn a blind eye' to a homeless body. As these physical alterations seem to complement the atmospheric dispersal tactics and the less immediately tangible legislation, then he can only assume that the PSPO is an example of the legislation too undergoing a transition from flexibility to rigidity, where the uncompromising methods of the anti-homeless benches have begun to inform the public ordinances: where public space architecture effectively 'talks' to legislation of its effectiveness. The detective feels the uncomfortable voice within again: that cannot be the purpose of this shaping and making of public space he is witnessing. The growing sense that he has been pursuing not a witness but a criminal all along begins to invade his mind. He fumbles for a cigarette to regain composure: being in the sanctioned seating area outside the four walls of the café, he can smoke. Reasserting his single-mindedness and dedication to the job at hand once again through a few long drags, he realises he still needs to know the answers to these questions in a practical sense, not for his own conscience but because what the legislation advises the officer to do in these circumstances, is going to affect whether the detective continues to look here or not. For the moment, he can only conclude that whatever a PSPO specifies is to be prohibited regardless of the situation, otherwise the whole point of giving clearer and workable categorisations of anti-social behaviour would be undone.

He tries to think again on what the witness would do on an average day, or having learnt a bit more about public space in a PSPO era, what she is not prohibited from doing. He realises he 
has gotten a little distracted by the history of the order and decides to make a summarised list of all the activities he has discovered are considered anti-social, jotting them down like bullet points. Once he has completed this, he does a little more research. He uncovers legislation guarding against 'inappropriate use of public toilets' (Council O. C., www.oxford.gov.uk, 2016), reinforcing the physical closure he has witnessed, but the obvious prohibition of 'urinating in public' (Crown T., Defining and measuring anti-social behaviour, 2004, p. 4) means that if she is going to perform biological functions like defecation, or again even physical desires like 'sexual conduct', she is likely going to be loitering somewhere most people do not go, and even then, with the threat of discovery she could not lurk long. Another rogue but insistent thought begins to mutter away at the back of his mind. Perhaps she has moved on? Not in the immediate sense implied by the PSPO, but actually moved town, become a refugee of public space, to somewhere that has not utilised a PSPO, or anything in the Anti-social Behaviour, Crime and Policing Act. The detective scours through local news websites to see if a PSPO is something that is commonly implemented or considered. Is his own town a unique case?

Committed now to fully informing himself of the context to his search in the hope it will make it more effective and efficient when he does eventually set off again, he discovers these measures are indeed occurring in other places. Oxford have specified 'aggressive begging' under a PSPO implemented in March 2016: 'aggressive', defined as 'begging near a cash machine' (Council O. C., www.oxford.gov.uk, 2015). On top of this, as well as covering all forms of begging in their recent PSPO, Swindon council have also added 'peddling' and 'marking surfaces' to their list of prohibited behaviours (Safe, www.swindon-csp.org.uk/, 2015). Concerning the last two, this has been done despite the majority of responses to peddling and chalking the pavement for money being positive (in a public engagement survey prior to 
the PSPO $63.94 \%$ of people said 'no' to prohibiting peddling, whilst $67.89 \%$ answered no to banning 'chalking' (Safe, www.swindon-csp.org.uk/, 2015).

Regardless, it is unlikely the witness has found the will (or the money considering the above) to move on: she is confined to this locale, a camp where the fences are increasingly not only formed from private property, but a concept of anti-social behaviour. In theory, this should help the detective in his search for it narrows down the potential areas, but in reality, all of what he has discovered, he must accept, is a big blow to his chances of success. He stayed in the town centre on the premise she would need to be here at some point, but he is now stumped: if she cannot beg for money or find a free to use public toilet here, where else can she pursue these things, in the immediate sense? It is as if there is an attempt to push her out into unobservable corners, whilst her needs pull her back into sight again, risking the attentions of the community support officers.

He is beyond vexed now, in fact a little worried. Learning about the PSPO is taking time from actually walking around and looking, but it is also leading his search in circles: the legislation and architecture is drawing him far from the town centre, but everything that he has presumed in his homeless profile directs him right back here. It would be more than a little humiliating to return to the office to report his failure. It is not as if homeless people are invisible, indeed they seem everywhere these days: but what they are, he realises in a flash of inspiration, is in constant threat of motion. He ponders on the idea of being pushed out until they are unobservable in relation to this new thought. Perhaps it is not just about clearing the homeless out of view, but forcing them into the 'perfect' picture of public space the PSPO wants to create. Effectively, disguising their presence through movement: that is the form of camp public space has become - a camp of motion. It is when a hunched figure rears its head in any noticeable way, such as breaking out from the current to ask for money or to lay down and sleep, that it is then surrounded, cordoned off and safely moved away, but maybe also, 
something he had not considered: reinserted into the stream. He has mostly been searching for clusters of homeless individuals sitting or camped somewhere (in a more figurative sense), even with his 'beggar trap' he assumed there would be a noticeable base in sight, but he should have been looking for homeless individuals living on the move as well. This realisation does little to help him. The issue is he cannot make any reliable, predictable estimates that will inevitably lead him to her: he is depending on blind luck and this makes him feel uncomfortable. As such, it is impossible to maintain an effective schedule.

He deflects the annoyance and concern away from a personal mistake. He can be forgiven for making this error in judgement, because these days he usually does not have much to do with legislation, only criminal law - it is not his fault if he was not made aware of the policy changes, and in truth, he is a little annoyed that he was not informed considering the situation he was being put into. These alterations just seemingly happened around him and he only noticed them by being affected in his work and by then it was too late. He could make that point to the council, or his superiors, but he is sure no one would really care, because it has not affected enough people to be a problem: it is not like this is a common pursuit for a detective. Or perhaps they would blame him for not working hard enough: he should have done his research. He is shocked then, to learn that breaking a PSPO is a 'level four criminal offence' (Office, 2014, p. 46) (emphasis added). Similarly, refusing to obey a dispersal order can result in a 'level 4 fine and/or up to three months in prison', whilst 'Failure to hand over items' is 'a level 2 fine' (Office, 2014, p. 32).

Being a detective, something in the wording of the PSPO immediately draws his attention. The 'Penalty on breach' is imposed by 'Enforcement officers' (Office, 2014, p. 46). The qualification of 'enforcement' seems suspicious. As he delves further, he finds out why: 'Section 71 ensures that bodies other than local authorities can make PSPOs in certain circumstances by order of the Secretary of State' (Office, 2014, p. 47). This would mean that 
'if a private security guard, potentially employed by a property developer, thinks you may have violated the PSPO, you must pay the fine or face prosecution' (Garrett, 2015), for they can be authorised to do so. This has made his job all the more difficult. Now he must consider private security companies and private land developers that surround the town centre and look into the potential conflicts they may have with homeless people, to see if that affects her whereabouts.

Although it was in 2014 that the Public Spaces Protection Order came into being, it did so in the backdrop of increasing specification of what anti-social behaviour was, of reports claiming to be 'measuring' such things (Crown T. , Defining and Measuring Anti-social Behaviour, 2004, p. 1): thus, why it can be found within the Anti-social Behaviour, Crime and Policing Act. Here was now state legislation which retained the earlier vagueness of targeting 'unreasonable' conduct, but by being something where the 'Restrictions and requirements' suggested in the 2004 report were 'set by the [local] council' (Office, 2014, p. 46) (or as the detective now knows, authorised others), specific and therefore practical categorisation was also assured. In fact, the PSPO could only come into existence through doing just that: certain misbehaviours being identified as relevant to its use. Yet this 'backdrop' was not just one of legislative organization, but also physical, architectural. When modifications occur and then one is told by supporting discourse that these are in response to a homeless 'problem', one is suddenly acutely aware of the lingering threat, even when there seem to be none present. On this note, the detective wonders exactly when these physical changes happened. He does not remember thinking one day 'oh, the park bench now has arm rests', but of course, his witness would: or rather, as he now does having been so told by local newspaper articles, she would perhaps think 'oh, the park bench now has an anti-sleeping feature'. At first perhaps, people do not notice these changes, but when they do, the effects seem to reproduce a narrative on which they were initially brought in for: it is when people do notice them that they are subsequently convinced of their need, and from which they form an image of the anti-social homeless, 
spectres lounging on benches, aggressively begging, or interrupting commuters. One day she is welcome, or at least tolerated and pitied, the next she is an irritant, even a danger to be warded away. He wonders briefly, what does that do to her perception of these places of last refuge, their atmospheres, and even of herself?

The detective therefore concludes that the use of PSPO's and the shaping of the public space architecture around him, seems to be part of a discourse which says that the homeless who do not have access to places to defecate or money to buy food right now, consequently have no defence against accusations of misbehaviour: 'Your council must help if you're legally homeless, but how much depends on your eligibility, your level of need and if your homelessness is your fault' (Crown T., www.gov.uk, 2016). He notes this down: is homelessness her fault? If so, anti-social behaviour is also, and the prohibitions justified. This realisation could definitely affect his search, for to fall outside of this notion of deserving poor, is to be immediately anti-socialised, until, for the very people who 'must help', anti-social behaviour and anti-social homeless are barely separable: 'Council bosses and police have been working together to tackle antisocial behaviour and the growing numbers of rough sleepers at the interchange' (Durkin, 2015) (emphasis added). He realises that here 'anti-social behaviour' and 'rough sleepers' are presented synonymously, or at least, the latter is the direct cause of the former. Hence, the power to disperse which is causing the detective all these problems.

He suddenly notices how late it is, the evening is closing in. Accepting he has done all he can for today (what more could he do?), he decides to go home. It has been a hard day but a good night's rest will refresh him enough to start again. He gets up, leaves a tip for the waiter, and jumps back into the rush of people: it's got busy again because commuters are now on their way home. It should be a prime opportunity to find her, for more commuters means increased chances of spare change, but commuter discomfort has changed that. This time however, as he walks, he is keeping a keen eye and attentive ear on the physicality of what is around him, for 
if today has taught him anything, it is that public space is indeed talking to him. Some of it is a whisper, legislation and acts one must actually investigate in order to be aware of them, but much of it is also right in front of him. Enough at least, to arouse one's suspicions and lead into inquiries regarding the legislative 'fog sweeping in' (Garrett, 2015). It indeed worked that way for him, and he is grateful for this lesson learnt today, but he is too tired to reflect on it anymore at this very moment.

He runs the final gauntlet as he nears the car park. He notices posters on the way to his car warning that to give spare change to beggars is merely to 'watch your money go up in smoke', or 'go to a fraud' (Allegretti, 2016), with pictures depicting a homeless person partaking in a cannabis joint. Under such messages, the modified benches seem less clandestine in their intentions but therefore more necessary. Indeed, he notes with interest the beggar is sitting, sedentary, which somehow adds to the intrusion. He sees more images, this time in a newspaper that blows along the street, which also tells us not to give money to beggars, for 'in most cases, you will be helping them to buy the drugs that could kill them' (Council W. B., 2015). The autonomy of the homeless figure is reduced to the status of a child, whose desires are to be constantly questioned by local councils, and even charities.

Yet as he walks passed the local church there is a sign outside informing homeless people they can register there to vote in the upcoming election. He is pleasantly surprised and somewhat relieved: just as his walk through the parks and streets today had begun to unsettle him, here at the very end, faith is restored. The detective is pleased to finish the day on a positive note - at least their situation does not rob them of the rights of a citizen, as it should be. The premise of liberal democracy - autonomy to choose political representation - is not undone and is present even here, amongst the homeless. There is a problem he has to admit, with the failure of the state to provide an existence for the street homeless beyond a 'bare life' (Agamben, 1998, p. 10) status. As a result, they are understood as individuals reduced to clients of 'necessity, mere 
physical existence', needing most urgently that which habitually we 'have in the household'. However, although uncomfortably meaning certain 'rights' become dormant in the face of such need, importantly for our detective's philosophical stability, this urgency does not after all disqualify them from a political status as 'speaking citizens in the polis' (Feldman, 2004, p. 15): surely a victory for democracy. In these thoughts, he does not progress: he cannot, his own ideology structures him, as it attempts to do with the homeless, who even here in their parlous condition. are being organized through a narrative of responsibility. If people like his witness can vote then, like him, they are agents who make choices, and therefore, as long as 'choices' appear available - like shelter - they also implicitly consent to these public space prohibitions. In other words, this foundation of political autonomy that the liberal state relies upon is seemingly being picked up on by local councils and repackaged into a localised context.

The apparent gift of citizenship is turned into a weapon. The messages are there if we look, encoded into public space, a hovering question mark over the involuntariness of homelessness, even in a liberal context: voluntarist theories of sovereignty reaching out to the homeless activate a narrative of autonomy which is retold in a more specific, exaggerated form to shoppers, home-dwellers, police officers and the homeless themselves. Anti-social behaviour is thus injected with autonomy and choice, but not to the point of the ridiculous. As the liberal equally cannot accept that anyone would 'choose' to sleep outside, an interloper appears to mystify the contradictions: drug addiction, the impossible madness of the homeless, and a loitering threat. All clash together to confuse the homeless voice. We end up with an apparently bizarre situation where, as Leonard C. Feldman argues, the homeless are indeed constructed as 'dependent shelterized subjects' (Feldman, 2004, p. 137), in which their individual rights are squeezed between this 'bare life' status and an anti-social behaviour discourse, but in contrast to his case are in fact not excluded from the political event that represents the individual as a political agent (and therefore justifies liberal democracy): the vote (Crown, 2016). A 
contradiction exists then, borne from our 'abstract liberal principles'. The homeless seemingly possess enough autonomy to choose a government and to justify prohibitive measures, but not enough to decide how to spend spare change that they are given.

This political autonomy is what separates the homeless from the refugee: for in theories of sovereignty that underpin our liberal democracies, the latter has 'bare life' covered, yet does not qualify for the political event. In fact, it is because of their non-qualification for the political, being non-citizens, that they cannot be allowed to 'choose' to reject the covering of 'bare life' when it is offered. Their status is reliant upon a state's decision (acknowledging the pressure of international bodies). The homeless however, because they do qualify as 'citizens', are at the mercy of local authorities, who are making the fulfilment of 'bare life' more difficult in reaction to their apparent 'choices' as citizens of the state.

Leonard Feldman utilises Agamben's 'sovereign ban' on Homo Sacer to emphasise the homeless plight in 'Citizens Without Shelter': a figure of ancient Rome who underlined 'bare life', an individual who could not be sacrificed for the sovereign had already sacrificed him, abandoned him and denied him a political status, thus consequently could be killed without legal recourse (Feldman, 2004, p. 16). Yet what we see under a liberal democracy, is it is not a ‘sovereign ban' on our modern day Homo Sacer's ‘bare life' which marks a political exclusion necessary for death, for under a liberal theory of democracy, it is in fact anxiety over the legitimacy of that sovereignty in the face of such political exclusion which has extended the major political event to the homeless. 'Bare life' denial has not resulted from political death, but has been caused by the organized maintenance of, however reduced, political life.

In short, liberalism creates this contradiction because it wants to protect the homeless autonomy to vote for that is what justifies liberal democracy. But in injecting a sense of autonomy in this way, liberal theorists are limited in the extent to which they can protect the homeless from the localised measures we are witnessing: the prohibitive PSPO, modified park bench, and bagpipe 
dispersal discourse, which makes up the current anti-social behaviour paradigm. The liberal solution cannot extend beyond either a refugee-like, shelterised camp of 'keep alive', or a prohibitive public space one reminiscent of Michel Foucault's 'let die' - a mechanism of biopolitics which allows death, in the form of an increasing exposure to death:

When I say 'killing,' I obviously do not mean simply murder as such, but also every form of indirect murder: the fact of exposing someone to death, increasing the risk of death for some people. Or, quite simply, political death, expulsion, rejection, and so on (Foucault, Society Must be Defended, 2004, p. 256).

It is only reminiscent, in my view, for unlike the 'paroxysmal development' of Nazi concentration camps Foucault refers to (Foucault, 2004, p. 259), we have seen that the 'letting die' in the historical moment of anti-social behaviour can come without the political death. Indeed, as suggested above, in this particular case it seems that it in fact emerges because of a 'political keeping alive' or 'political half-life': however low down on the list of priorities voting may be for the street homeless, it is nevertheless still present, and so therefore is a sense of 'half-autonomy' in everything else they do. In this, we can perhaps say that failure to exercise such a power confirms our presumptions of the homeless as drug-addled, drop outs or fraudsters. The 'right' to vote becomes damning evidence. In this narrative however, there is something missing: in the transition from voluntarist, state theory, to localised issues of antisocial behaviour, the autonomy of the homeless ceases to be about political choices, and becomes problems of misbehaviour. Thus, this construction of the anti-social homeless subject opens up a camp of public space, where a form of 'let die' is buffered by the autonomy given to them by liberal voluntarism: Liberal theory needs a 'self-manifestation of the state' (Foucault, Security, Territory, Population, 2009, p. 344), and in this need for 'political life' to be maintained, the day to day freedoms of the homeless are not in fact reinforced, but sacrificed upon this altar of 'self-manifestation'. As such, the liberal must realise the real choice - his own - between a commitment to 'abstract' principles of negative freedom and a legitimate theory of 
sovereignty: he cannot have both. Whichever one is chosen, will have ramifications for the concept of autonomy.
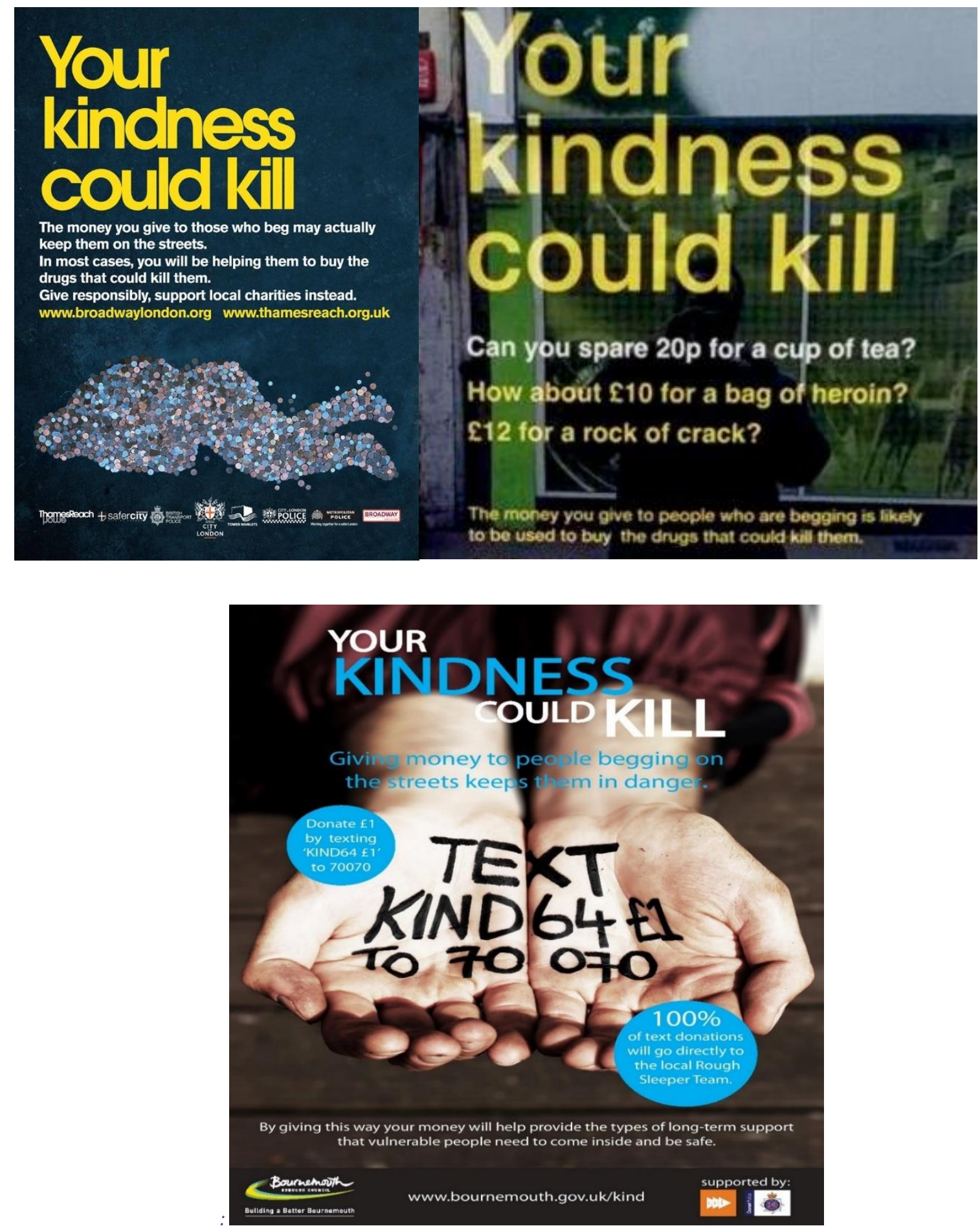


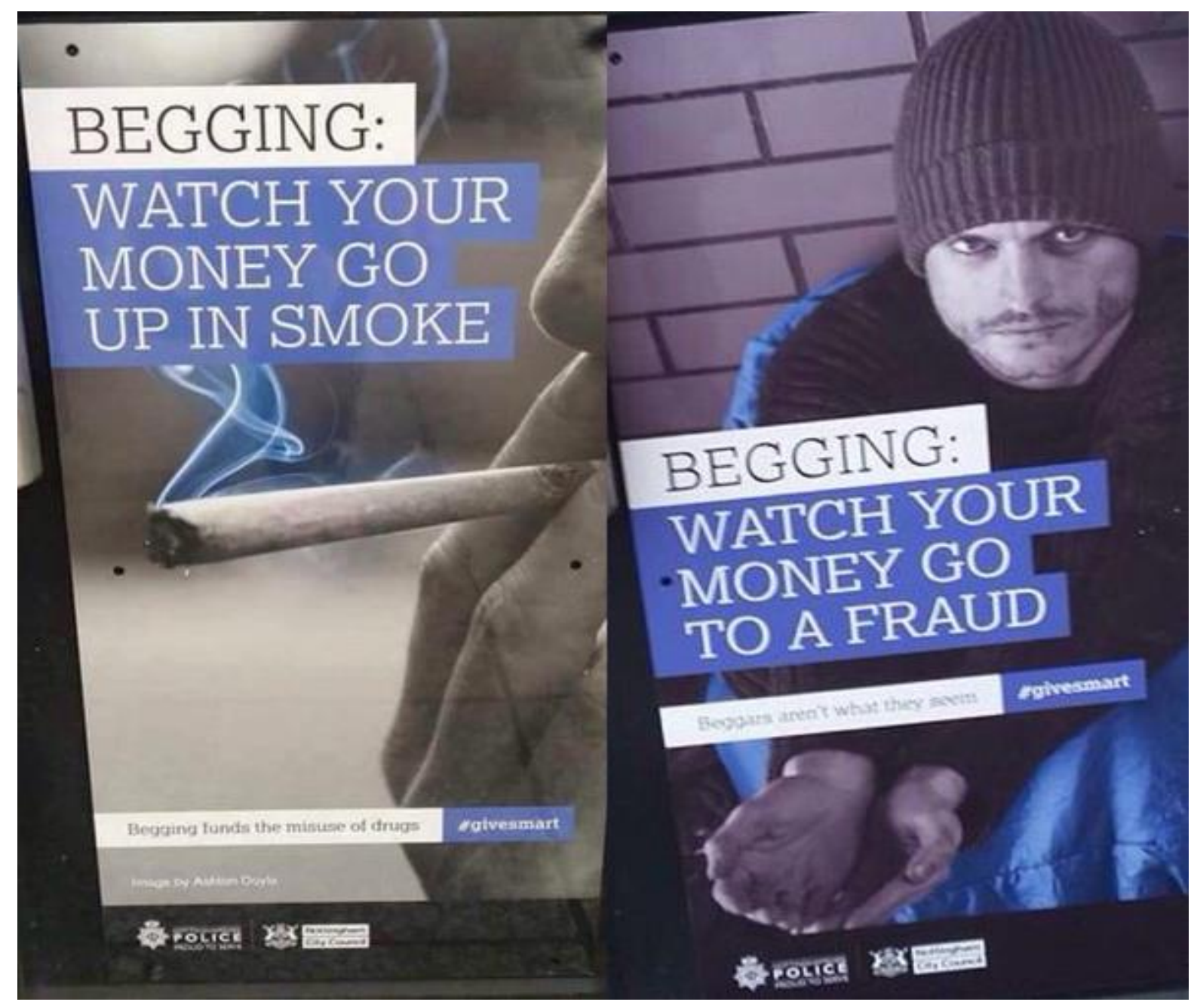

Figures 15-18 (left to right, above):

The City of London, in partnership with the Metropolitan police, produce a poster discouraging giving money to beggars: http://www.thamesreach.org.uk/news-and-views/campaigns/giving-to-beggars/

Ipswich joins the campaign against kindness: https://www.opendemocracy.net/ourkingdom/ric-lander-amie-robertson/howdid-it-come-to-this-help-homeless-posters-tell-public-that-

Bournemouth follows suit, albeit with a slightly less abrasive message: http://www.bournemouthecho.co.uk/news/11370091._Your_kindness_could_kill_don_t_hand_cash_over_to_beggars_on the street public \%20urged/

Nottingham council show the more 'hard communitarian' blame discourse: http://www.independent.co.uk/news/uk/homenews/nottingham-city-council-anti-begging-homeless-poster-campaign-demonising-outrage-a6949916.html 
This critique never reaches our detective's thoughts however, for now his mind is on home and he cannot wait to be there, away from it all. He needs a break from the noise and bombardment. As if on purpose, reacting to his thoughts, when he climbs up the stairs of the multi-storey car park, a distant wailing sound greets his ears. It is the bagpipes again, also playing here. $\mathrm{He}$ hums along to a tune he does not know, as it tells the story of a parallel world in which spaces have dual functions. On his way home now, he is already forgetting that other place within the same space that he has visited, like a tourist. In spite of his tiredness he is surprised to find the music a pleasant accompaniment in the time it takes for him to pay for his ticket, walk to his car and get in behind the wheel. But then he is passing through and not looking for shelter. 


\section{References}

Agamben G. (1998). Homo sacer, 1st ed. Stanford, CA: Stanford University Press.

Allegretti A. (2016). Nottingham Council's 'GiveSmart' Anti-Begging Posters Branded 'Utterly Reprehensible'. huffingtonpost.co.uk, 24 March. Retrieved from http://www.huffingtonpost.co.uk/entry/nottingham-councils-anti-begging-posters-sparkoutrage_uk_56f3a670e4b08af01bea15e7

Council C. B. (2015). www.chelmsford.gov.uk, 20 October. Retrieved from http://www.chelmsford.gov.uk/sites/chelmsford.gov.uk/files/files/committee_files/public\% 20space\%20protection\%20order\%20report.pdf

Council E. C. (2015). www.benbradshaw.co.uk, 15 December. Retrieved from http://www.benbradshaw.co.uk/exeter_city_council_letter_on_pspos

Council H. B. (2015). Update on Hackney's Public Space Protection Order. hackney.gov.uk, 3 June. Retrieved from http://news.hackney.gov.uk/update-on-hackneys-publicspace-protection-order

Council O. C. (2015). www.oxford.gov.uk, October. Retrieved from https://www.oxford.gov.uk/downloads/file/2264/oxford city centre pspo

Council O. C. (2016a). Foresters tower public spaces protection order. www.oxford.gov.uk, October. Retrieved from https://www.oxford.gov.uk/info/20101/community_safety/274/public_spaces_protection_o $\underline{\text { rders }}$

Council O. C. (2016b). www.oxford.gov.uk. Retrieved from www.Oxford_city_centre_PSPO_Overview_October_2015.pdf

Council O. C. (2016c). www.oxford.gov.uk/downloads. Retrieved from https://www.oxford.gov.uk/downloads/file/2264/oxford_city_centre_pspo

Council W. B. (2015). www.woking.gov.uk/news. Retrieved from http://www.woking.gov.uk/news/archive?item=000055E07CD4.C0A801BA.00001204.000 $\underline{B}$

Crown. (2016). Voter registration forms (paper versions). www.gov.uk, 10 June. Retrieved from https://www.gov.uk/government/publications/voter-registration-forms-paper-versions 
Crown T. (1998). The Crime and Disorder Act 1998 chapter 37. London, UK: The Stationery Office Limited.

Crown T. (2000). Police research series paper 123: Policing anti-social behaviour. London, UK: The Home Office.

Crown T. (2004). Defining and measuring anti-social behaviour. London, UK: The Home Office.

Crown T. (2014). Anti-social Behaviour, Crime and Policing Act 2014. www.legislation.gov.uk. Retrieved from http://www.legislation.gov.uk/ukpga/2014/12/section/2/enacted

Crown T. (2016a). Emergency housing if you're homeless. www.gov.uk, 23 September. Retrieved from https://www.gov.uk/emergency-housing-if-homeless

Crown T. (2016b). Criminal Justice and Public Order Act. Retrieved from http://www.legislation.gov.uk/ukpga/1994/33/part/V/crossheading/powers-in-relation-to$\underline{\text { raves }}$

Durkin J. (2015). Council bosses tackle antisocial behaviour with bagpipe music to deter rough sleepers. Daily Echo, 14 November. Retrieved from http://www.bournemouthecho.co.uk/news/14030597.Bournemouth_council_s_latest_sche me_to_deter_the_homeless_bagpipe_music/?ref=fbpg

Feldman L. C. (2004). Citizens without shelter. New York, NY: Cornell University Press.

Foucault M. (2004). Society must be defended. London, UK: Penguin Books.

Foucault M. (2009). Security, territory, population, 1st ed. London, UK: Palgrave Macmillan.

Garrett B. L. (2015). PSPOs: the new control orders threatening our public spaces.

Guardian, 8 September. Retrieved from https://www.theguardian.com/cities/2015/sep/08/psposnew-control-orders-public-spaces-asbos-freedoms

Gentleman A. (2014). Three charged with stealing food from skip behind Iceland supermarket. Guardian, 28 January. Retrieved from https://www.theguardian.com/uk-news/2014/jan/28/threecharged-vagrancy-act-food-skip-iceland 
Guess R. (2003). Public goods, private goods, 2nd ed. Princeton, NJ: Princeton University Press.

Haddock B. (2011). Contingency and judgement in history of political philosophy: A phenomenoligcal approach. In Stears J. F. (Ed.), Political philosophy versus history (pp. 6584). Cambridge, UK: Cambridge University Press.

Kelling J. W. (1982). Broken windows. Atlantic Monthly, 249, 29-38.

Nietzsche F. (2005). Twilight of the idols. In Norman A. R. (Ed.), The Anti-Christ, Ecce Homo, Twilight of the Idols, and other writings (pp. 153-231). Cambridge, UK: Cambridge University Press.

Oakeshott M. (1962). The voice of poetry in the conversation of mankind. In Oakeshott M. (Ed.), Rationalism in politics (pp. 488-541). Indianapolis, IN: Liberty Fund.

Oakeshott M. (1967). Rationalism in politics and other essays, 2nd ed. London, UK: Methuen \& Co Ltd.

Office H. (2014). Anti-social Behaviour, Crime and Policing Act 2014: Reform of anti-social behaviour powers Statutory guidance for frontline professionals. London, UK: Crown.

Osborne H. (2015). Hackney council in east London drops threat to fine rough sleepers. Guardian 5 June. Retrieved from https://www.theguardian.com/uk-news/2015/jun/05/hackneycouncil-drops-threat-to-fine-rough-sleepers

Parkinson J. R. (2012). Democracy and public space, 1st ed. Oxford, UK: Oxford University Press.

Safe K. S. (2015). Swindon town centre PSPO. Keeping Swindon Safe. Retrieved from: http://www.swindon-csp.org.uk/asb/Pages/pspo.aspx

Strauss L. (1988). What is political philosophy?, 2nd ed. London, UK: The University of Chicago Press.

Waldron J. (1991). Homelessness and the issue of freedom. UCLA Review, 39, 295-324. 
